Functional characterization and expression of GASCL1 and GASCL2, two anther-specific chalcone synthase like enzymes from Gerbera hybrida

\title{
Kontturi, Juha
}

2017-02

Kontturi , J , Osama , R , Deng , X, Bashandy , H , Albert , V A \& Teeri , T H 2017 , ' Functional characterization and expression of GASCL1 and GASCL2, two anther-specific chalcone synthase like enzymes from Gerbera hybrida ', Phytochemistry, vol. 134 , pp. 38-45 . https://doi.org/10.1016/j.phytochem.2016.11.002

http://hdl.handle.net/10138/201880

https://doi.org/10.1016/j.phytochem.2016.11.002

acceptedVersion

Downloaded from Helda, University of Helsinki institutional repository.

This is an electronic reprint of the original article.

This reprint may differ from the original in pagination and typographic detail.

Please cite the original version. 
Functional characterization and expression of GASCL1 and GASCL2, two anther-specific chalcone synthase like enzymes from Gerbera hybrida

Juha Kontturi ${ }^{1}$, Raisa Osama ${ }^{1}$, Xianbao Deng ${ }^{1,2}$, Hany Bashandy ${ }^{1,3}$, Victor A. Albert ${ }^{4}$ and Teemu H. Teeri ${ }^{1,5}$

${ }^{1}$ Department of Agricultural Sciences, Viikki Plant Science Centre, P.O. Box 27, University of Helsinki, Helsinki FIN-00014, Finland

2Present address: Key Laboratory of Plant Germplasm Enhancement and Specialty Agriculture, Wuhan Botanical Garden of the Chinese Academy of Sciences, Wuhan 430074, People's Republic of China.

${ }^{3}$ Department of Genetics, Cairo University, 13 Gamaa St., Giza 12619, Egypt

${ }^{4}$ Department of Biological Sciences, University of Buffalo, USA

${ }^{5}$ For correspondence (email teemu.teeri@ helsinki.fi)

Corresponding author: Teemu H. Teeri, Department of Agricultural Sciences, Viikki Plant Science Centre, P.O. Box 27, University of Helsinki, Helsinki FIN-00014, Finland; tel +358-2941-58380; fax +358-2941-58727; email teemu.teeri@ helsinki.fi

\title{
Highlights
}

- Two anther-specific chalcone synthases (ASCLS) from Gerbera hybrida were characterized

- GASCL1 and GASCL2 are tri-and tetraketidesynthases that utilize long chain acyl-CoA starters

- GASOZ and GASO2 have tapetum localized expression

- This study extends the well-characterized type III polyketide synthase family from Gerbera hybrida to two members that are very distinct from chalcone synthase

\begin{abstract}
The chalcone synthase superfamily consists of type III polyketidesynthases (PKSs), enzymes responsible for producing plant secondary metabolites with various biological and pharmacological activities. Anther-specific chalcone synthase-like enzymes (ASCLs) represent an ancient group of type III PKSs involved in the biosynthesis of sporopollenin, the main component of the exine layer of moss spores and mature pollen grains of seed plants. In the latter, ASCL proteins are localized in the tapetal cells of the anther where they participate in sporopollenin biosynthesis and exine formation within the locule. It is thought that the enzymes responsible for sporopollenin biosynthesis are highly conserved, and thus far, each angiosperm species with a genome sequenced has possessed two ASCL genes, which in Arabidopsis thaliana are PKSA and PKSB. The Gerbera hybrida (gerbera) PKS protein family consists of three chalcone synthases (GCHS1, GCHS3 and GCHS4) and three 2-pyrone synthases (G2PS1, G2PS2 and G2PS3). In previous
\end{abstract}


studies we have demonstrated the functions of chalcone synthases in flavonoid biosynthesis, and the involvement of 2-pyrone synthases in the biosynthesis of antimicrobial compounds found in gerbera. In this study we expanded the gerbera PKS-family by functionally characterizing two gerbera ASCL proteins. In vitro enzymatic studies using purified recombinant proteins showed that both GASCL1 and GASCL2 were able to use medium and long-chain acyl-CoA starters and perform two to three condensation reactions of malonyl-CoA to produce tri- and tetraketide 2-pyrones, usually referred to as alpha-pyrones in sporopollenin literature. Both GASCL1 and GASCL2 genes were expressed only in floral organs, with most expression observed in anthers. In the anthers, transcripts of both genes showed strict tapetum-specific localization.

Keywords: Gerbera hybrida; Asteraceae; type III polyketide synthase; ASCL; sporopollenin

\section{Introduction}

The surface of the pollen grain can be divided into three separate layers. The outer layer is called exine, a multilayered complex structure made up of a chemically resistant biopolymer called sporopollenin. The inner layer, intine, is mostly composed of cellulose. Pollen grains are also covered by a pollen coat, composed of lipids, proteins, pigments and aromatic compounds, which fill the cavities of exine. The exine gives protection against pathogen attack, dehydration, UV irradiation and plays a role in pollination by interacting with the female stigmatic cells. Based on present understanding, the components of the exine are synthesized by the surrounding sporophytic tapetal cells and transferred on the surface of developing microspores within the locule (Ariizumi and Toriyama, 2011; Edlund et al., 2004; Quilichini et al., 2015). Due to its high resistance to chemical and physical degradation, the exact structure of sporopollenin has been difficult to resolve, but phenolics and fatty acids have been suggested to be likely components (Ahlers et al., 1999; Guilford et al., 1988). The biosynthesis of sporopollenin has also remained unclear. Recent studies have identified the involvement of fatty acid biosynthesis-related genes in sporopollenin biosynthesis (Chen et al., 2011; de Azevedo Souza et al., 2009; M orant et al., 2007). Two independent research groups identified two enzymes similar to chalcone synthases involved in sporopollenin biosynthesis in Arabidopsis, and their physiological role in sporopollenin biosynthesis was shown through mutation studies. The enzymes were named PKSA and PKSB. Single mutations in the genes encoding these proteins led to abnormal exine patterning, and the double mutation to male sterility (Dobritsa et al., 2010; Kim et al., 2010; M izuuchi et al., 2008).

The chalcone synthase superfamily consists of type III polyketidesynthases (PKSs), enzymes responsible for producing structurally different and biologically active plant secondary metabolites having roles in antimicrobial defense, UV photoprotection, flower pigmentation, and pollen fertility (Austin and Noel, 2003; Kim et al., 2010). Type III PKS enzymes are abundant in vascular plants but they have also been characterized from the moss Physcomitrella patens (Kim et al., 2013). Type III plant polyketide synthases are relatively small (40-45 kDa) homodimeric proteins that catalyze the sequential decarboxylative condensation reaction between malonyl-CoA and $a$ variety of CoA-linked starter molecules. Starter molecules may vary from short to long chain aliphatic moieties, but also aromatic molecules such as p-coumaroyl-CoA are used. PKSs that are able to utilize methylmalonyl- or ethylmalonyl-CoA as an extender molecule in addition to malonyl-CoA have also been characterized (Jez et al., 2000; Schröder et al., 1998). The polyketide reaction is initiated by a starter molecule loading on to the active-site Cys, which is followed by 
malonyl-CoA decarboxylation, polyketide chain elongation, and in many cases enzymatically catalyzed cyclization of the polyketide intermediate (M orita et al., 2007). The best characterized type III polyketide synthase is chalcone synthase (CHS), which catalyzes the first step in the biosynthesis of plant flavonoids. CHS is a tetraketide synthase that uses $\mathrm{p}$-coumaroyl-CoA as a starter substrate in a condensation reaction with three keto units from malonyl-CoA to form naringenin chalcone (Ferrer et al., 1999).

Genes encoding enzymes with sequence similarity to $\mathrm{CHS}$ and shown to be expressed in the tapetum cells of the anther have been isolated from Brassica napus (Shen and Hsu, 1992), Oryza sativa (Hihara et al., 1996), Nicotiana sylvestris (Atanassov et al., 1998) and Silene latifolia (Barbacar et al., 1997). Atanassov et al. (1998) showed that the anther-specific CHS-like enzymes belong to a separate subfamily of plant type III PKSs. They relate to CHS in gene and amino acid sequence and catalytic mechanism, but have a different substrate preference and are often referred to as anther-specific CHS-like enzymes (ASCLs). M izuuchi and coworkers (2008) characterized two Arabidopsis ASCLs, PKSA and PKSB, which accepted unusually long (up to $\mathrm{C}_{20}$ chain length) fatty acyl CoAs as starter substrates and catalyzed the sequential condensation reaction of a starter-CoA and malonyl-CoA to produce alpha-pyrones in vitro. Nishikawa et al. (2005) found Arabidopsis mutants with reduced pollen-stigma adhesion (less adhesive pollen, lap) and discovered that the exine patterning was altered, resulting in structurally weakened pollen grains that easily collapsed in these lines. Dobritsa et al. (2010) mapped LAP6 and LAP5 to two CHS-like genes, PKSA and PKSB. At the same time, Kim et al. (2010) identified a role for LAP6/PKSA and LAP5/PKSB in sporopollenin biosynthesis, initially through coexpression with ACOS5, a key gene in the process. On the basis of these results and work done with fatty-acyl metabolism enzymes, a model for sporopollenin biosynthesis in Arabidopsis was established (Grienenberger et al., 2010; Quilichini et al., 2015). The model proposes that in a reaction sequence localized to the ER, ASCLs work together with cytochrome P450-enzymes (M orant et al., 2007), fatty acyl-CoA synthetase (ACOS) (de Azevedo Souza et al., 2009), and tetraketide alpha-pyrone reductases (Grienenberger et al., 2010) to produce polyhydroxylated tetraketide products incorporated directly or after modifications into the sporopollenin polymer. The polyhydroxylation of the polyketide has been suggested to provide multiple places for cross-linking the polyketide product and other potential sporopollenin components such as fatty acids and fatty alcohols by ester and ether bonds. This has been used to explain the cross-linked nature of sporopollenin and its resistance to chemical and physical degradation (Kim et al., 2010; Scott et al., 2004). It has also been suggested that sporopollenin biosynthetic enzymes could work as a metabolon (Lallemand et al., 2014).

Gerbera hybrida is a commercially important ornamental plant species that is a member of the sunflower family, Asteraceae. Gerbera has been used as a model plant for flower and inflorescence development (Broholm et al., 2008; Juntheikki-Palovaara et al., 2014; Tähtiharju et al., 2012; Zhao et al., 2016) and type III PKS research. We have previously shown that gerbera contains three chalcone synthases involved in the flavonoid pathway (Deng et al., 2014; Helariutta et al., 1995). Additionally it contains a triketide synthase G2PS1 that is responsible for the biosynthesis of triacetolactone (4-hydroxy-6-methyl-2-pyrone), a putative precursor for antimicrobial compounds, the aglycones of gerberin (5,6-dihydro-4-hydroxy-6-methyl-2-pyrone) and parasorboside (tetrahydro-4-hydroxy-6-methyl-2-pyrone) (Eckermann et al., 1998; Koskela et al., 2011). Recently we expanded the number of known gerbera PKS family proteins by showing 
that the genome encodes two pentaketide synthases, G2PS2 and G2PS3, which are involved in the biosynthesis of 4-hydroxy-5-methylcoumarin, another antimicrobial compound in gerbera (Pietiäinen et al., 2016). In the present study, we further extend the gerbera PKS protein family by functionally characterizing two proteins, GASCL1 and GASCL2, orthologous to Arabidopsis PKSA and PKSB, as part of the growing number of ASCL proteins that form a family believed to be functionally and evolutionally conserved in land plants (Quilichini et al., 2015; Wang et al., 2013). Interestingly, while the first sequenced gymnosperm genomes (Nystedt et al. 2013; Neale et al., 2014) contain a single ASCL gene, all angiosperms with a genome sequenced possess these two genes for ASCL proteins. The proteins can be divided into two separate groups based on whether they possess either Ala or Val at position 220/214 (Arabidopsis numbering). All ASCLs can be identified as either Ala-clade or Val-clade proteins (Jepson et al., 2014). Gerbera ASCL-genes share 72-73 \% sequence similarity with the Arabidopsis PKSA and PKSB genes and 77-79 \% amino acid sequence identity with their encoded proteins. Phylogenetically, the genes are part of the ASCLgene family, and GASCL1 belongs to the Ala-, and GASCL2 to the Val-subclade of ASCLs. The GASCL1 and GASCL2 genes are specifically expressed in the tapetal cells of the anther. In vitro enzyme assays with recombinant GASCL1 and GASCL2 proteins showed that they are able to use middle and long chain aliphatic acyl-CoA starters and make two to three condensation reactions with malonyl-CoA to produce tri- and tetraketide alpha-pyrone products.

\section{Results and discussion}

\subsection{Analysis and isolation of gerbera ASCL-genes}

RNA-sequencing of gerbera anther libraries indicated that anthers express two CHS-like genes that were not previously characterized. GASCL1 was obtained in full length; it contained a 1173 nucleotide long open reading frame (ORF) and showed $77 \%$ sequence identity with Arabidopsis PKSA at the deduced amino acid level. GASCL2 lacked 59 nucleotides from the 5' of the gene. Using genome walking we were able to sequence the missing 5' end of GASCL2 and generate a 1167 nucleotide long ORF that shared $79 \%$ sequence identity, at the encoded amino acid level, with the Arabidopsis PKSB protein. A phylogenetic tree based on known or putative ASCL nucleotide sequences (Fig. 1) showed that both genes are part of the ASCL gene family, separate from the plant non-ASCL type III PKSs. An amino acid alignment (Fig. S1) showed that GASCL1 has the amino acid Ala at the position 218, similar to PKSA (at position 220), and therefore belongs to the Ala-clade of ASCLs. GASCL2, on the other hand, belongs to the Val-clade proteins together with PKSB, as described by Jepson and coworkers (2014). A similar Ala-Val separation into two different sister-clades was also observed in the phylogenetic tree using DNA sequences.

\subsection{In vitro enzyme activity of GASCL1 and GASCL2}

Recombinant GASCL1 and GASCL2 proteins with N-terminal His-tags were produced in E.coli in a soluble form, purified using Ni-affinity chromatography and visualized in SDS-PAGE (Fig. 2). The enzymatic activity of recombinant GASCL1 and GASCL2 were tested using in vitro assays. When acetyl-CoA was used in the assays, only GASCL1 was able to make a product, the triketide triacetolactone (4-hydroxy-6-methyl-2-pyrone) (Table1, compound 1), based on retention time and the mass of the reference compound. GASCL2 did not show any activity with acetyl-CoA. This result is similar to that reported by M izuuchi et al. (2008), who found that PKSA from Arabidopsis, 
but not PKSB, was able to utilize short-chain CoA starters. Neither GASCL1 nor GASCL2 accepted pcoumaroyl-CoA or benzoyl-CoA as starters. Both enzymes accepted hexanoyl- or octanoyl-CoA as substrates, and single major peaks were observed in chromatograms. Other smaller peaks were observed in the mass spectra (Fig. S2), which appeared to be due to loss of $\mathrm{CO}_{2}\left([\mathrm{M}-\mathrm{H}-44]^{-}\right)$from the parent ion, indicating the presence of an alpha-pyrone ring. Based on the mass, elemental composition, fragmentation pattern and the enzyme activity of other known ASCLs (Jepson et al., 2014; M izuuchi et al., 2008) the products were characterized as alpha-pyrone triketides (Table 1, compounds 2 and $\mathbf{3}$ ).

When stearoyl-CoA $\left(\mathrm{C}_{18}\right)$ was used in the assays, two peaks were observed in the chromatogram (Fig. 3A) with retention times of $8.39 \mathrm{~min}(\mathrm{~m} / \mathrm{z} 391)$ and $8.94 \mathrm{~min}(\mathrm{~m} / \mathrm{z} 349)$; these were not observed in the empty vector control (Fig. 3B). A similar loss of $\mathrm{CO}_{2}\left([\mathrm{M}-\mathrm{H}-44]^{-}\right)$from the parent ion was observed in the mass spectra of both products (Fig. 3C and 3D). Based on the mass, elemental composition, loss of $\mathrm{CO}_{2}$ from the parent ion, and the results by Kim et al. (2010) who observed exactly the same $\mathrm{m} / \mathrm{z}$ values in the products when $\mathrm{C}_{18}$-CoA was used, the products were identified as triketide- (4) and tetraketide (5) alpha-pyrones. The triketide product (relative peak area 7159) was the main product observed in the M S-analysis compared to the tetraketide (relative peak area 52). Also, Jepson et al. (2014) observed that the ASCL from Hypericum perforatum, HpPKS1, was able to synthetize a tetraketide product when the carbon number was extended to $\mathrm{C}_{14}-\mathrm{Co}$ A or $\mathrm{C}_{18^{-}}$ COA.

All known and characterized plant ASCL enzymes are able to synthetize tri- and tetraketide products from hydroxylated medium chain starters (e.g. $12-\mathrm{OH}-\mathrm{C}_{18}-\mathrm{Co}$ and $\mathrm{C}_{18}-\mathrm{Co} \mathrm{A}$ ) and have a stronger preference for them over the analogous unsubstituted substrates. Therefore, ASCL enzymes are called hydroxyalkylpyrone synthases (Jepson et al., 2014; Quilichini et al., 2015). Unfortunately, these compounds were not available for this study. Grienenberger et al. (2010) characterized two tapetum-specific alpha-pyrone tetraketidereductases from Arabidopsis that reduce the carbonyl function of the tetraketide alpha-pyrone but do not act on the triketides synthesized by PKSA or PKSB. This suggests that the tetraketide is the physiological product, although the triketide product was the main compound produced in our experiments and also in other in vitro studies (Jepson et al., 2014; Kim et al., 2010). Our results suggest that a long chain starter would be the physiological substrate in gerbera, since both GASCL1 and GASCL2 produced the tetraketide from stearoyl-CoA only, but not from the shorter-chain CoAs.

\subsection{Expression studies and in situ hybridization analysis}

The expression profiles of GASCL1 and GASCL2 genes were tested in various gerbera organs, including a pooled anther sample from the early stages of anther development, as in Helariutta et al. (1993). The qPCR results showed that expression was low (in relation to GGAPDH) in all plant parts (Fig. 4). The highest expression was detected in flower organs, where it was strongest in anthers. Practically no expression was detected in the inflorescence stem (scape), leaves or roots. Kim et al. (2010) observed that PKSB was expressed exclusively in flowers, while PKSA had some expression in leaves, roots and stems. Little is known about the role of ASCLs outside non-anther tissues. Jepson et al. (2014) demonstrated that the expression of HpPKS1 from Hypericum perforatum was upregulated by abscisic acid (ABA) and downregulated by jasmonic acid (JA) and wounding in leaves. Based on these observations, they suggested that HpPKS1 and other Ala-clade ASCLs could be involved in the biosynthesis of minor cell wall components in non-anther tissues. Based on our observations, GASCL1 and GASCL2 are flower-specific, with highest expression 
observed in anthers. M ost likely they do not play any role in leaves since hardly any expression was observed there.

The in situ hybridization method was used to see if tapetum-specific expression could be observed as has been described in Arabidopsis (Kim et al., 2010). Gerbera anthers were collected for in situ studies and gene-specific antisense and sense probes were used. Both GASCL1 and GASCL2 antisense probes showed strong hybridization signal exclusively in the tapetum (Fig. 5). The sense probes did not give any hybridization signal.

The small proportion of tapetal cells in the anther tissue explains why transcript levels in whole anthers are quite low. Tapetum is the innermost sporophytic layer of the anther and offers both lipidic and phenylpropanoid precursors for the developing microspores. Based on current knowledge, the components of the exine are synthesized in these surrounding sporophytic tapetal cells and transferred to the surface of developing microspores within the locule in Arabidopsis (Ariizumi and Toriyama, 2011; Quilichini et al., 2015; Wang et al., 2013). In the tapetal cells, the synthesized and reduced, esterified fatty acids yield CoAs. CoA esters are further processed by PKSs and reductases. The resulting polyhydroxylated tetraketide compounds are then exported from the tapetal cells by the ABCG26 transporter and/or LTPs to the developing microspores for polymerization and for further processing by unknown enzymes (Grienenberger et al., 2010; Quilichini et al., 2014; Quilichini et al., 2015). Our results on gerbera are in line with the idea that ASCLs catalyze biosynthetic reactions in the tapetum, where they take part in the metabolic pathway leading to sporopollenin biosynthesis.

\section{Conclusions}

The pollen cell wall's resistance to abiotic and biotic stresses has played a crucial role when plants invaded land (Blackmore et al., 2007). The enzymes responsible for the biosynthesis of sporopollenin are believed to be conserved in land plants. ASCLs form an ancient group of type III polyketide synthases that are involved in the biosynthesis of sporopollenin. Thus far there have been only four vascular plant species in which ASCLs have been functionally characterized (Jepson et al., 2014; Quilichini et al., 2015). In this study we examined two ASCLs from gerbera. Both GASCL1 and GASCL2 genes were expressed only in floral organs, with most expression observed in anthers. M ore specifically, they were both tapetum-specific. In vitro enzymatic studies showed that both GASCL1 and GASCL2 proteins were able to use medium and long chain acyl-CoAs with malonyl-COA to perform two to threecondensation reactions to produce tri- and tetraketide alphapyrones. Further study is needed to explore the substrate preference of hydroxylated long chain CoAs as has been described in other species (Colpitts et al., 2011; Jepson et al., 2014; Wang et al., 2013).

In addition to the chalcone synthases from the flavonoid pathway and the 2-pyrone synthases involved in the biosynthesis of antimicrobial compounds, RNA-sequencing from anthers has shown that gerbera possess two ASCLs. GASCL1 and GASCL2, described in this study, extend the gerbera type III PKS-family, which is now composed of eight members.

\section{Experimental}

\subsection{Chemicals and plant material}


Acetyl-CoA, benzoyl-CoA, hexanoyl-CoA, octanoyl-CoA, stearoyl-CoA, malonyl-CoA, 4-hydroxy-6methyl-2-pyrone (triacetolactone) were purchased from Sigma-Aldrich (Steinheim, Germany) and p-coumaroyl-CoA from M icroCombiChem (Wiesbaden, Germany). The Gerbera hybrida (G. jamesonii Bolus ex Adlam $\times$ G. viridifolia Schultz-Bip) cultivar Terraregina was obtained from Terra Nigra B.V. (De Kwakel, The Netherlands). Plants were grown in greenhouse conditions as described previously (Deng et al., 2012).

\subsection{Identification and phylogenetic analysis gerbera ASCL sequences}

RNA sequencing from gerbera inflorescence stage eight anthers revealed two genes (GASCL1 and GASCL2) which showed 72-73\% sequence similarity to Arabidopsis PKSA and PKSB. GASCL1 was full length (1173 bp), but the ORF of GASCL2 was lacking 59 nucleotides from the 5 ' end. A GenomeWalker Universal kit was used (Clontech, CA, USA) to obtain the missing 5' end. GenomeWalker DNA libraries were constructed according to the manufacturer's instructions. Libraries were used in the primary PCR with adaptor primer 1 (Table S1) and the gene specific primer in the $3^{\prime}$ end. In the secondary PCR, the other adaptor primer 2 was used with the gene specific primer to produce fragments which were then cloned to the vector pJET1.2 blunt end cloning vector (Thermo Scientific). Multiple alignment (based on amino acids) of 26 identified or putative ASCLs, gerbera type III PKS family and a CHS from M edicago sativa was performed using the prank tool (ebi.ac.uk/goldman-srv/webprank), whereafter the aligned amino acid sequences were converted to the corresponding nucleotide sequences using an in-house program tool. The phylogenetic analysis using this nucleotide alignment was generated using RAxML (embnet.vitalit.ch/raxml-bb) with the GTR plus gamma model in a maximum likelihood bootstrap search. For the visualization of the phylogenetic tree, FigTree v1.4.2 was used

(tree.bio.ed.ac.uk/software/figtree).

\subsection{Protein expression in E.coli}

GASCL1 was PCR amplified from cDNA made from stage eight gerbera anthers and for GASCL2, the full length cDNA in pJET1.2 vector was used as a template. PCR products were cloned into Ncol and Xhol sites of the expression vector pHIS8 (Ferrer et al., 1999), which creates 8 Histidines to the $\mathrm{N}$-terminus of the expressed protein. Plasmids isolated from E. coli strain $\mathrm{DH} 5 \alpha$ were verified by sequencing and then plasmids transformed to the strain Lemo21 (New England Biolabs). An overnight starter culture was used to initiate $50 \mathrm{ml}$ cultures which were grown to $\mathrm{OD}_{600}$ of 0.5 and induced by $0.5 \mathrm{mM}$ IPTG. Cultures were grown at $+16^{\circ} \mathrm{C}$ for 22 hours. Pelleted cultures were lyzed with B-PER Bacterial Protein Extraction Reagent (Thermo Scientific) supplemented with $20 \mathrm{mM}$ imidazole, lysozyme $(100 \mu \mathrm{g} / \mathrm{ml})$, DNase I $(5 \mathrm{U} / \mathrm{ml})$ and a protease inhibitor (cOmplete mini EDTA free, Roche). Proteins were purified using His SpinTrap columns (GE Healthcare) according to the manufacturer's instructions. Finally PD M iniTrap G-25 columns (GE Healthcare) were used for buffer exchange.

\subsection{Enzymatic assays}

$30 \mu \mathrm{g}$ of purified protein was used in $100 \mu \mathrm{l}$ of $0.1 \mathrm{M}$ Tris-HCl assay buffer (pH 7.5) containing 2 $\mathrm{mM}$ DTT, $80 \mu \mathrm{M}$ malonyl-CoA and $40 \mu \mathrm{M}$ starter substrate. As a control, the empty pHIS8-vector was used. Activity with various starters was tested, including acetyl-CoA, benzoyl-CoA, hexanoylCoA, octanoyl-CoA, stearoyl-CoA and p-coumaroyl-CoA. Reaction was stopped after one hour with $20 \mu \mathrm{l}$ of glacial acetic acid, followed by two times extraction with $300 \mu$ l ethyl acetate which was then evaporated to dryness. 


\subsection{UPLC-M S analysis}

Reaction products were dissolved in $100 \mu \mathrm{l}$ of methanol and the metabolites were separated on an Acquity UPLC $® B E H C 18$ column $(1.7 \mu \mathrm{m}, 50 \times 2.1 \mathrm{~mm}$, Waters, Ireland $)$ at $40^{\circ} \mathrm{C}$. The mobile phase consisted of $(A)$ water and $(B)$ acetonitrile (Chromasolv ${ }^{\circledR}$ grade, Sigma-Aldrich, Steinheim, Germany) both containing $0.1 \%$ formic acid (Sigma-Aldrich, Steinheim, Germany). Waters Synapt G2 HDM S mass spectrometer (Waters, Milford MA, USA) was interfaced with the Waters Acquity UPLC $®$ system (Waters, Milford MA, USA) via an ESI source. Mass range was 100 to 600 . Samples were analyzed in negative ion mode, with capillary voltage at $3.0 \mathrm{kV}$. The source temperature was $120^{\circ} \mathrm{C}$ and desolvation temperature was set to $360{ }^{\circ} \mathrm{C}$. Linear gradient went from $95 \%$ of $\mathrm{A}$ to 10 $\%$ in 10 min, then back to $95 \%$ in $10.1 \mathrm{~min}$ and left to equilibrate for $2 \mathrm{~min}$. The injection volume was $2 \mu \mathrm{l}$ and flow-rate of the mobile phase was $0.6 \mathrm{ml} / \mathrm{min}$.

\subsection{Expression studies}

RNA was extracted from various gerbera tissues using the pine tree method described by Chang et al. (1993). RNA was purified using NucleoSpin RNA Clean-up kit (M acherey-Nagel) and 500 ng of total RNA was used in cDNA synthesis using SuperScript III Reverse Transcriptase kit (Invitrogen). $180 \mu \mathrm{l}$ of M Q water was added to dilute the CDNA for qRT-PCR which was done using LightCycler 480 Real-Time PCR detection unit (Roche). The PCR reaction contained $5 \mu$ of diluted CDNA, $7.5 \mu l$ of LightCycler 480 SYBR Green I M aster mix, $1 \mu$ l of M Q water and $0.5 \mu \mathrm{M}$ forward and reverse primers. The PCR- program started with one initial cycle of $95^{\circ} \mathrm{C}$ for $10 \mathrm{~min}$, followed by 45 cycles of $95^{\circ} \mathrm{C}$ for $10 \mathrm{~s}, 60^{\circ} \mathrm{C}$ for $10 \mathrm{~s}$ and $72{ }^{\circ} \mathrm{C}$ for $10 \mathrm{~s}$. Relative expression values were calculated by the method described by Pffafl (2001) and normalized against the gerbera housekeeping gene GAPDH as described in Deng et al. (2014).

For in situ hybridization, anthers were collected from outermost disc flowers at stage six of inflorescence development (Helariutta et al., 1993). Samples were fixed overnight, dehydrated in an ethanol gradient series and embedded to paraffin as described earlier (Elomaa et al., 2003). Anthers were then transversely cut to $10 \mu \mathrm{m}$ sections and spread on precharged slides. For sense and antisense GASCL1 and GASCL2 probe synthesis, 154 and 215 bp fragments with no sequence similarity to each other were PCR-amplified from the cloned pHIS8-constructs. A T7 polymerase binding site was added to the forward primer for sense amplification or to the reverse primer for antisense amplification. For the probe synthesis, DIG RNA labelling kit (Roche) was used. Hybridization protocol was carried out as described earlier (Karlgren et al., 2009) except that hybridizations were done at $42^{\circ} \mathrm{C}$.

\section{Acknowledgements}

We thank J.P. Noel for providing the expression vector pHIS8. In addition we thank Nina Sipari at the Viikki M etabolomics Unit, University of Helsinki for MS analysis. Anu Rokkanen and Eija Takala are thanked for great technical assistance in the laboratory. This research was supported by the Academy of Finland (grant 139513 for T.H.T.), J.K. was funded by the Doctoral Programme in Plant Sciences (DPPS) at the University of Helsinki.

\section{Figure legends, tables and references}




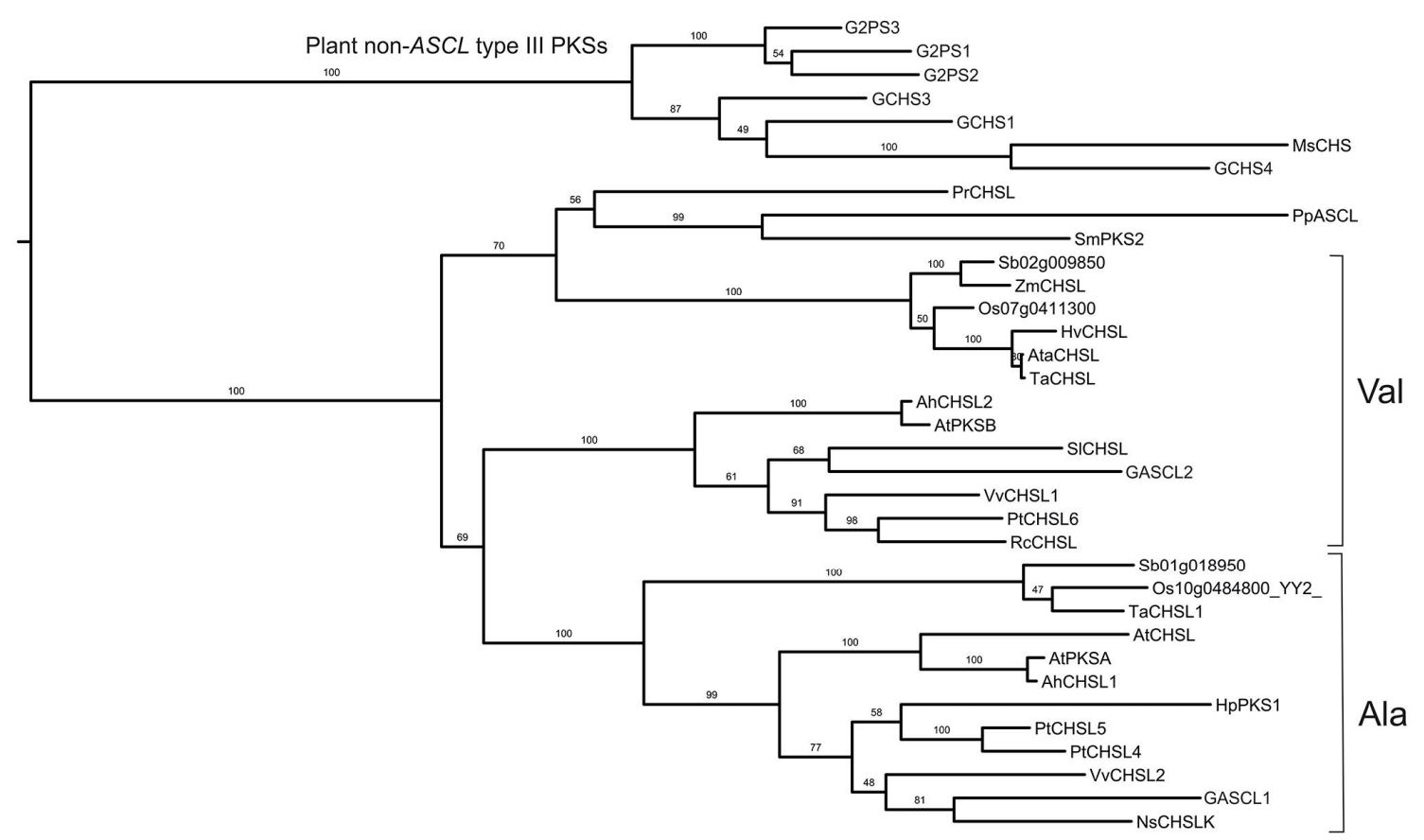

Fig 1. Phylogenetic tree of gerbera GASCL1 and GASCL2 genes together with 26 known ASCLs. As plant non-ASCL type III PKSs, gerbera chalcone synthases (GCHS1-3), gerbera 2-pyrone synthases (G2PS1-3) and a CHS from M edicago sativa were included. Ala and Val subclades are marked to the tree. List of plant species and accession numbers can be found in Table S2.

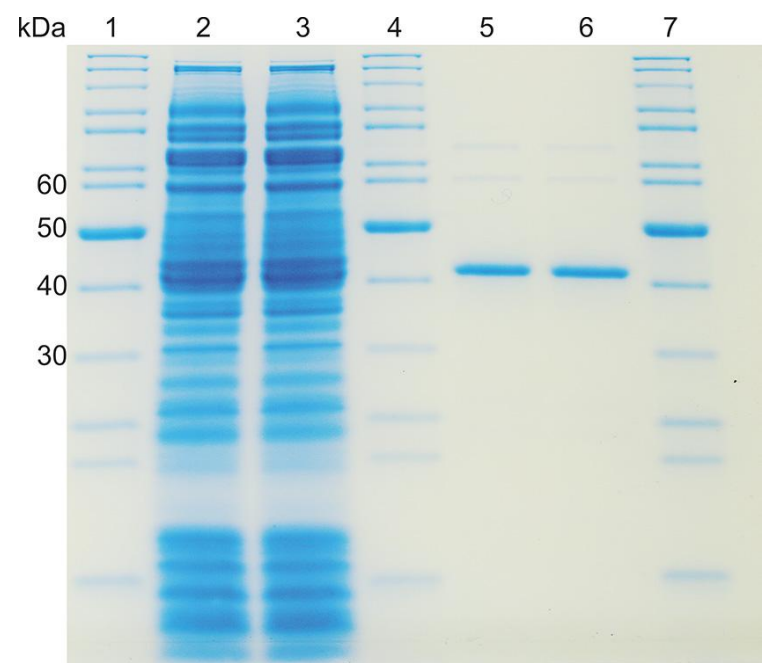

Fig 2. SDS-page of soluble proteins produced in E. coli. Lanes 1, 4 and 7 show the protein standard. Lanes 2 and 3, the total soluble fractions of E.coli expressing GASCL1 and GASCL2, respectively. Lanes 5 and 6 , the purified GASCL1 and GASCL2 proteins. 

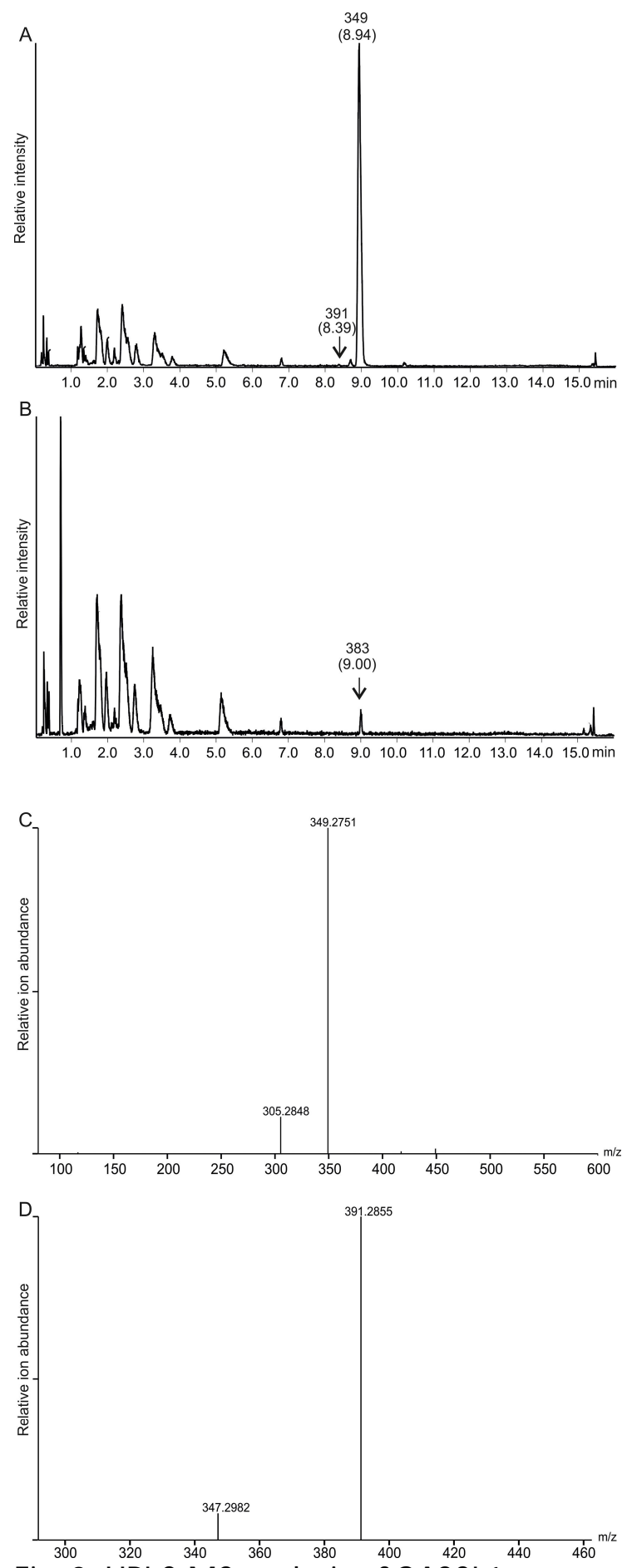

Fig. 3. UPLC-M S analysis of GASCL1 enzyme activity when assayed with malonyl-CoA and stearoylCoA. Base peak intensity (BPI) chromatogram of enzyme activity with GASCL1 (A) and vector control (B). Triketide (m/z 349, Rt $8.94 \mathrm{~min}$ ) and tetraketide (m/z 391, Rt $8.39 \mathrm{~min}$ ) products were observed in the enzyme assays when either GASCL1 or GASCL2 was used but not in the empty vector control. The peak with retention time of 9.0 min in the vector control was a different compound ( $\mathrm{m} / \mathrm{z}$ 383). (C and D) M ass spectra of the triketide (C) and tetraketide (D) products. Loss of $\mathrm{CO}_{2}$ was observed in both products indicating presence of an alpha-pyrone ring. With these susbstrates, the enzyme activities were identical with GASCL1 and GASCL2. 


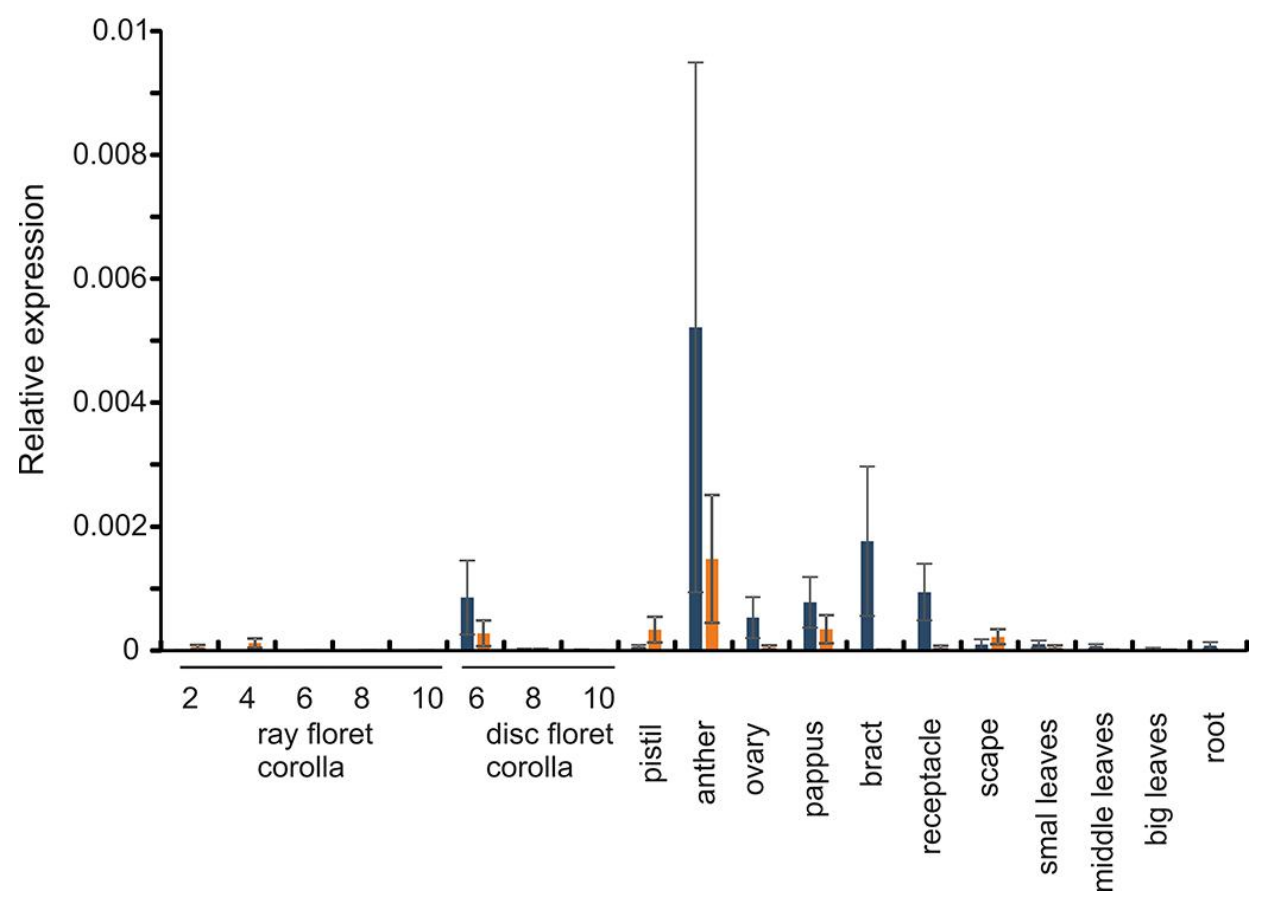

Fig. 4. Expression pattern of GASCL1 (blue) and GASCL2 (orange) in different gerbera tissues. Expression in anthers was measured from pooled samples collected at stages six, seven and eight of gerbera inflorescence development as described in Helariutta et al. (1993). Expression of the genes were normalized against the GAPDH gene from gerbera. Error bars represent standard error of the mean, number of replicates was 3.

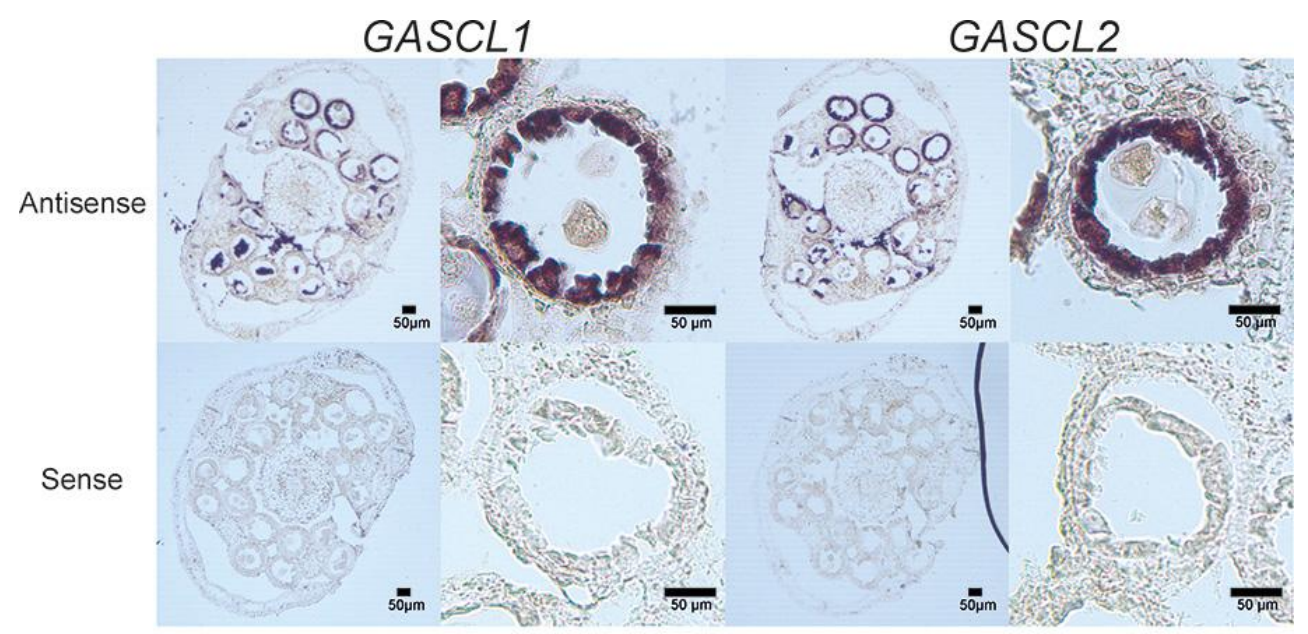

Fig. 5. GASCL1 and GASCL2 mRNA were localized to the tapetal cells of the anthers using gene specific antisense and sense probes. The control (sense) probe did not give any hybridization signal. Scale bars, $50 \mu \mathrm{m}$. 
Table 1. In vitro products in the GASCL1 and GASCL2 enzyme assays. Both enzymes had identical activity except that GASCL2 did not produce compound 1 (triacetolactone).

\begin{tabular}{|c|c|c|c|c|c|}
\hline $\begin{array}{l}\text { Starter } \\
\text { CoA }\end{array}$ & Proposed structure of the compound & $\begin{array}{l}\text { Elemental } \\
\text { composition }\end{array}$ & $\begin{array}{l}\text { Retention } \\
\text { time }\end{array}$ & $\begin{array}{l}m / z \\
{[M-H]^{-}}\end{array}$ & $\begin{array}{l}\mathrm{m} / \mathrm{z} \\
{\left[\mathrm{M}-\mathrm{CO}_{2}-\mathrm{H}\right]^{-}} \\
\text {(rel. int. to } \\
\text { major ion) } \\
15 \mathrm{eV}\end{array}$ \\
\hline $\begin{array}{l}\text { Acetyl - } \\
\text { CoA }\end{array}$ & $\underbrace{O}_{\mathrm{OH}}$ & $\mathrm{C}_{6} \mathrm{H}_{5} \mathrm{O}_{3}$ & 0.38 & 125.0234 & $\begin{array}{l}81.0365 \\
(-)\end{array}$ \\
\hline $\begin{array}{l}\text { Hexanoyl- } \\
\text { CoA }\end{array}$ & $\begin{array}{l}\mathrm{O}_{\mho} \\
2\end{array}$ & $\mathrm{C}_{10} \mathrm{H}_{13} \mathrm{O}_{3}$ & 2.09 & 181.0878 & $\begin{array}{l}137.0977 \\
(100)\end{array}$ \\
\hline $\begin{array}{l}\text { Octanoyl- } \\
\text { CoA }\end{array}$ & $\begin{array}{l}\mathrm{O} \\
3\end{array}$ & $\mathrm{C}_{12} \mathrm{H}_{17} \mathrm{O}_{3}$ & 3.65 & 209.1185 & $\begin{array}{l}165.1289 \\
(100)\end{array}$ \\
\hline $\begin{array}{l}\text { Stearoyl- } \\
\text { CoA }\end{array}$ & $\mathrm{O}_{\mho}$ & $\mathrm{C}_{22} \mathrm{H}_{37} \mathrm{O}_{3}$ & 8.94 & 349.2751 & $\begin{array}{l}305.2848 \\
(22)\end{array}$ \\
\hline $\begin{array}{l}\text { Stearoyl- } \\
\text { CoA }\end{array}$ & Y & $\mathrm{C}_{24} \mathrm{H}_{39} \mathrm{O}_{4}$ & 8.39 & 391.2855 & $\begin{array}{l}347.2982 \\
(12)\end{array}$ \\
\hline
\end{tabular}




\section{References}

Ahlers, F., Thom, I., Lambert, J., Kuckuk, R., Rolf Wiermann, 1999. 1H NM R analysis of sporopollenin from Typha Angustifolia. Phytochemistry 50, 1095-1098.

Ariizumi, T., Toriyama, K., 2011. Genetic regulation of sporopollenin synthesis and pollen exine development. Annu. Rev. Plant. Biol. 62, 437-460.

Atanassov, I., Russinova, E., Antonov, L., Atanassov, A., 1998. Expression of an anther-specific chalcone synthase-like gene is correlated with uninucleate microspore development in Nicotiana sylvestris. Plant M ol. Biol. 38, 1169-1178.

Austin, M.B., Noel, J.P., 2003. The chalcone synthase superfamily of type III polyketide synthases. Nat. Prod. Rep. 20, 79-110.

Barbacar, N., Hinnisdaels, S., Farbos, I., M oneger, F., Lardon, A., Delichere, C., M ouras, A., Negrutiu, I., 1997. Isolation of early genes expressed in reproductive organs of the dioecious white campion (Silene latifolia) by subtraction cloning using an asexual mutant. Plant J. 12, 805-817.

Blackmore, S., Wortley, A.H., Skvarla, J.J., Rowley, J.R., 2007. Pollen wall development in flowering plants. New Phytol. 174, 483-498.

Broholm, S.K., Tahtiharju, S., Laitinen, R.A., Albert, V.A., Teeri, T.H., Elomaa, P., 2008. A TCP domain transcription factor controls flower type specification along the radial axis of the Gerbera (Asteraceae) inflorescence. Proc. Natl. Acad. Sci. U. S. A. 105, 9117-9122.

Chang S., Puryear J., Cairney J., 1993. A Simple and Efficient M ethod for Isolating RNA from Pine Trees. Plant M olecular Biology Reporter 11, 113-116.

Chen, W., Yu, X.H., Zhang, K., Shi, J., De Oliveira, S., Schreiber, L., Shanklin, J., Zhang, D., 2011. Male Sterile2 encodes a plastid-localized fatty acyl carrier protein reductase required for pollen exine development in Arabidopsis. Plant Physiol. 157, 842-853.

Colpitts, C.C., Kim, S.S., Posehn, S.E., Jepson, C., Kim, S.Y., Wiedemann, G., Reski, R., Wee, A.G., Douglas, C.J., Suh, D.Y., 2011. PpASCL, a moss ortholog of anther-specific chalcone synthase-like enzymes, is a hydroxyalkylpyrone synthase involved in an evolutionarily conserved sporopollenin biosynthesis pathway. New Phytol. 192, 855-868.

de Azevedo Souza, C., Kim, S.S., Koch, S., Kienow, L., Schneider, K., M cKim, S.M., Haughn, G.W., Kombrink, E., Douglas, C.J., 2009. A novel fatty Acyl-CoA Synthetase is required for pollen development and sporopollenin biosynthesis in Arabidopsis. Plant Cell 21, 507-525.

Deng, X., Bashandy, H., Ainasoja, M., Kontturi, J., Pietiainen, M., Laitinen, R.A.E., Albert, V.A., Valkonen, J.P.T., Elomaa, P., Teeri, T.H., 2014. Functional diversification of duplicated chalcone synthase genes in anthocyanin biosynthesis of Gerbera hybrida. New Phytol. 201, 1469-1483. 
Deng, X., Elomaa, P., Nguyen, C.X., Hytonen, T., Valkonen, J.P.T., Teeri, T.H., 2012. Virus-induced gene silencing for Asteraceae-a reverse genetics approach for functional genomics in Gerbera hybrida. Plant Biotechnology Journal 10, 970-978.

Dobritsa, A.A., Lei, Z., Nishikawa, S., Urbanczyk-Wochniak, E., Huhman, D.V., Preuss, D., Sumner, L.W., 2010. LAP5 and LAP6 Encode Anther-Specific Proteins with Similarity to Chalcone Synthase Essential for Pollen Exine Development in Arabidopsis. Plant Physiol. 153, 937-955.

Eckermann, S., Schroder, G., Schmidt, J., Strack, D., Edrada, R.A., Helariutta, Y., Elomaa, P., Kotilainen, M., Kilpelainen, I., Proksch, P., Teeri, T.H., Schroder, J., 1998. New pathway to polyketides in plants. Nature 396, 387-390.

Edlund, A.F., Swanson, R., Preuss, D., 2004. Pollen and stigma structure and function: the role of diversity in pollination. Plant Cell 16, 84-97.

Elomaa, P., Uimari, A., M ehto, M., Albert, V.A., Laitinen, R.A., Teeri, T.H., 2003. Activation of anthocyanin biosynthesis in Gerbera hybrida (Asteraceae) suggests conserved protein-protein and protein-promoter interactions between the anciently diverged monocots and eudicots. Plant Physiol. 133, 1831-1842.

Ferrer, J.L., Jez, J.M., Bowman, M.E., Dixon, R.A., Noel, J.P., 1999. Structure of chalcone synthase and the molecular basis of plant polyketide biosynthesis. Nat. Struct. Biol. 6, 775-784.

Grienenberger, E., Kim, S.S., Lallemand, B., Geoffroy, P., Heintz, D., de Azevedo Souza, C., Heitz, T., Douglas C.J., Legrand, M. 2010. Analysis of TETRAKETIDE a-PYRONE REDUCTASE Function in Arabidopsis thaliana Reveals a Previously Unknown, but Conserved, Biochemical Pathway in Sporopollenin Monomer Biosynthesis. Plant Cell 22, 4067-4083.

Guilford, W.J., Schneider, D.M., Labovitz, J., Opella, S.J., 1988. High resolution solid state C NM R spectroscopy of sporopollenins from different plant taxa. Plant Physiol. 86, 134-136.

Helariutta, Y., Elomaa, P., Kotilainen, M., Griesbach, R.J., Schroder, J., Teeri, T.H., 1995. Chalcone Synthase-Like Genes Active during Corolla Development are Differentially Expressed and Encode Enzymes with Different Catalytic Properties in Gerbera-Hybrida (Asteraceae). Plant M ol. Biol. 28, 47-60.

Helariutta, Y., Elomaa, P., Kotilainen, M., Seppanen, P., Teeri, T.H., 1993. Cloning of cDNA coding for dihydroflavonol-4-reductase (DFR) and characterization of dfr expression in the corollas of Gerbera hybrida var. Regina (Compositae). Plant M ol. Biol. 22, 183-193.

Hihara, Y., Hara, C., Uchimiya, H., 1996. Isolation and characterization of two cDNA clones for mRNAs that are abundantly expressed in immature anthers of rice (Oryza sativa L.). Plant M ol. Biol. 30, 1181-1193. 
Jepson, C., Karppinen, K., Daku, R.M ., Sterenberg, B.T., Suh, D.Y., 2014. Hypericum perforatum hydroxyalkylpyrone synthase involved in sporopollenin biosynthesis--phylogeny, site-directed mutagenesis, and expression in nonanther tissues. FEBS J. 281, 3855-3868.

Jez, J.M., Austin, M.B., Ferrer, J.L., Bowman, M.E., Schroder, J., Noel, J.P., 2000. Structural control of polyketide formation in plant-specific polyketide synthases. Chem. Biol. 7, 919-930.

Juntheikki-Palovaara, I., Tahtiharju, S., Lan, T., Broholm, S.K., Rijpkema, A.S., Ruonala, R., Kale, L., Albert, V.A., Teeri, T.H., Elomaa, P., 2014. Functional diversification of duplicated CYC2 clade genes in regulation of inflorescence development in Gerbera hybrida (Asteraceae). Plant J. 79, 783-796.

Karlgren, A., Carlsson, J., Gyllenstrand, N., Lagercrantz, U., Sundstrom, J.F., 2009. Non-radioactive in situ hybridization protocol applicable for Norway spruce and a range of plant species. J. Vis. Exp. 26, 1205.

Kim, S.Y., Colpitts, C.C., Wiedemann, G., Jepson, C., Rahimi, M., Rothwell, J.R., M clnnes, A.D., Hasebe, M., Reski, R., Sterenberg, B.T., Suh, D., 2013. Physcomitrella PpORS, Basal to Plant Type III Polyketide Synthases in Phylogenetic Trees, Is a Very Long Chain 2 '-Oxoalkylresorcinol Synthase. J. Biol. Chem. 288, 2767-2777.

Kim, S.S., Grienenberger, E., Lallemand, B., Colpitts, C.C., Kim, S.Y., Souza, C.d.A., Geoffroy, P., Heintz, D., Krahn, D., Kaiser, M., Kombrink, E., Heitz, T., Suh, D., Legrand, M., Douglas, C.J., 2010. LAP6/POLYKETIDE SYNTHASE A and LAP5/POLYKETIDE SYNTHASE B Encode Hydroxyalkyl alphaPyrone Synthases Required for Pollen Development and Sporopollenin Biosynthesis in Arabidopsis thaliana. Plant Cell 22, 4045-4066.

Koskela, S., Soderholm, P.P., Ainasoja, M., Wennberg, T., Klika, K.D., Ovcharenko, V.V., Kylanlahti, I., Auerma, T., Yli-Kauhaluoma, J., Pihlaja, K., Vuorela, P.M., Teeri, T.H., 2011. Polyketide derivatives active against Botrytis cinerea in Gerbera hybrida. Planta 233, 37-48.

Lallemand, B., Erhardt, M., Heitz, T., Legrand, M., 2013. Sporopollenin biosynthetic enzymes interact and constitute a metabolon localized to the endoplasmic reticulum of tapetum cells. Plant Physiol. 162, 616-625.

M izuuchi, Y., Shimokawa, Y., Wanibuchi, K., Noguchi, H., Abe, I., 2008. Structure Function Analysis of Novel Type III Polyketide Synthases from Arabidopsis thaliana. Biol. Pharm. Bull. 31, 2205-2210.

M orant, M., Jorgensen, K., Schaller, H., Pinot, F., M oller, B.L., Werck-Reichhart, D., Bak, S., 2007. CYP703 is an ancient cytochrome P450 in land plants catalyzing in-chain hydroxylation of lauric acid to provide building blocks for sporopollenin synthesis in pollen. Plant Cell 19, 1473-1487.

M orita, H., Kondo, S., Oguro, S., Noguchi, H., Sugio, S., Abe, I., Kohno, T., 2007. Structural insight into chain-length control and product specificity of pentaketide chromone synthase from Aloe arborescens. Chem. Biol. 14, 359-369.

Neale, D.B., Wegrzyn, J.L., Stevens, K.A., Zimin, A.V., Puiu, D., Crepeau, M.W., Cardeno, C., Koriabine, M., Holtz-M orris, A.E., Liechty, J.D. and Martínez-García, P.J. et al. 2014. Decoding the 
massive genome of loblolly pine using haploid DNA and novel assembly strategies. Genome Biology 15, R59.

Nishikawa S.I, Zinkl G.M ., Swanson R.J., M aruyama D., and Preuss D., 2005. Callose ( $\beta-1,3$ glucan) is essential for Arabidopsis pollen wall patterning, but not tube growth. BM C Plant Biology. 5:22.

Nystedt, B., Street, N.R., Wetterbom, A., Zuccolo, A., Lin, Y.C., Scofield, D.G., Vezzi, F., Delhomme, N., Giacomello, S., Alexeyenko, A., Vicedomini, R., Sahlin, K., Sherwood, E., Elfstrand, M., Gramzow, L., Holmberg, K., Hallman, J., Keech, O., Klasson, L., Koriabine, M., Kucukoglu, M., Kaller, M., Luthman, J., Lysholm, F., Niittyla, T., Olson, A., Rilakovic, N., Ritland, C., Rossello, J.A., Sena, J., Svensson, T., Talavera-Lopez, C., Theissen, G., Tuominen, H., Vanneste, K., Wu, Z.Q., Zhang, B., Zerbe, P., Arvestad, L., Bhalerao, R., Bohlmann, J., Bousquet, J., Garcia Gil, R., Hvidsten, T.R., de Jong, P., M acKay, J., M organte, M., Ritland, K., Sundberg, B., Thompson, S.L., Van de Peer, Y., Andersson, B., Nilsson, O., Ingvarsson, P.K., Lundeberg, J., Jansson, S., 2013. The Norway spruce genome sequence and conifer genome evolution. Nature 497, 579-584

Pfaffl, M.W., 2001. A new mathematical model for relative quantification in real-time RT-PCR. Nucleic Acids Res. 29, e45.

Pietiäinen, M ., Kontturi, J., Paasela, T., Deng, X., Ainasoja, M., Nyberg, P., Hotti, H.,Teeri, T.H., 2016. Two polyketide synthases are necessary for 4-hydroxy-5-methylcoumarin biosynthesis in Gerbera hybrida. In press, 10.1111/tpj.13216.

Quilichini, T.D., Grienenberger, E., Douglas, C.J., 2015. The biosynthesis, composition and assembly of the outer pollen wall: A tough case to crack. Phytochemistry 113, 170-182.

Quilichini, T.D., Samuels, A.L., Douglas, C.J., 2014. ABCG26-mediated polyketide trafficking and hydroxycinnamoyl spermidines contribute to pollen wall exine formation in Arabidopsis. Plant Cell $26,4483-4498$.

Schroder, J., Raiber, S., Berger, T., Schmidt, A., Schmidt, J., Soares-Sello, A.M., Bardshiri, E., Strack, D., Simpson, T.J., Veit, M ., Schroder, G., 1998. Plant polyketide synthases: a chalcone synthasetype enzyme which performs a condensation reaction with methylmalonyl-CoA in the biosynthesis of C-methylated chalcones. Biochemistry 37, 8417-8425.

Scott, R.J., Spielman, M., Dickinson, H.G. 2004. Stamen Structure and Function. The Plant Cell 16, 46-60.

Shen, J.B., Hsu, F.C., 1992. Brassica anther-specific genes: characterization and in situ localization of expression. M ol. Gen. Genet. 234, 379-389.

Tähtiharju, S., Rijpkema, A.S., Vetterli, A., Albert, V.A., Teeri, T.H., Elomaa, P., 2012. Evolution and diversification of the CYC/TB1 gene family in Asteraceae--a comparative study in Gerbera (Mutisieae) and sunflower (Heliantheae). Mol. Biol. Evol. 29, 1155-1166.

Wang, Y., Lin, Y.C., So, J., Du, Y., Lo, C., 2013. Conserved metabolic steps for sporopollenin precursor formation in tobacco and rice. Physiol. Plant. 149, 13-24. 
Zhao, Y., Zhang, T., Broholm, S.K., Tähtiharju, S., M ouhu, K. Albert, V., Teeri, T.H., Elomaa, P. 2016. Co-opting floral meristem identity genes for patterning of the flower-like Asteraceae inflorescence. Plant Physiology, in press.

\section{Appendix A. Supplementary data}

Table S1. Primers used in the study.

Table S2. Plant species used in construction of the phylogenetic tree and amino acid alignment.

Figure S1. Figure S1. Amino acid alignments of 26 identified or putative ASCLs, gerbera type III PKS family and a CHS from M edicago Sativa generated with prank (www.ebi.ac.uk/goldmansrv/webprank). Grouping to Ala- or Val clades of ASCL proteins is based on the position marked with an asterix. For generating the phylogenetic tree in Figure 1, the alignment was converted to nucleotides.

Fig. S2. Figure S2. M ass spectra of triketide products produced by GASCL1 and GASCL2. Loss of $\mathrm{CO}_{2}$ was observed in the mass spectra when either hexanoyl-CoA (A), octanoyl-CoA (B) or acetyl-CoA (C and D) was used in the enzyme assays and remained ions [M -CO2-H]- with $\mathrm{m} / \mathrm{z} 165$ (A), 137 (B) and 81 (D - M SM S data) were observed. 


\section{Supporting information}

Table S1. Primers used in the study.

$\begin{array}{lll}\text { Name } & \text { Sequence (5'-3') } & \text { Application } \\ \text { GASCL1_qPCR_F } & \text { GGCAACTCTTCAGCAACTAGG } & \text { qPCR } \\ \text { GASCL1_qPCR_R } & \text { GGATGTGGCCATGAAAGAGA } & \text { qPCR } \\ \text { GASCL__qPCR_F } & \text { CACTAATTGCGATGATCCTGAAC } & \text { qPCR } \\ \text { GASCL_qPCR_R } & \text { CTCACAAGCCTGCATCAAAA } & \text { qPCR } \\ \text { qPCR GGAPDH_F } & \text { CCAGGAACCCAGAGGAGATACC } & \text { qPCR } \\ \text { qPCR GGAPDH_R } & \text { GGAGCGGATATGATGACCTTCTTG } & \text { qPCR } \\ \text { GASCL1_F_SET7 } & \text { CATAATACGACTCACTATAGGGGGCAACTCTTCAGCAACTAGG } & \text { in situ } \\ \text { GASCL1_R_AST7 } & \text { CATAATACGACTCACTATAGGGTCTCTTCATGGCCACATCC } & \text { in situ } \\ \text { GASCL__F_SET7 } & \text { CATAATACGACTCACTATAGGGCACTAATTGCGATGATCCTGAAC } & \text { in situ } \\ \text { GASCL__R_AST7 } & \text { CATAATACGACTCACTATAGGGTITGATGCAGGCTTGTGAG } & \text { in situ } \\ \text { GASCL1_pHIS8_F } & \text { CGTGGTTCCCATGGCATGTCAAAGGCCAATGGCAAC } & \text { pHIS8 cloning } \\ \text { GASCL1_pHIS8_R } & \text { TCGAATTCCTCGAGTTAGTTGAGGCTACGAAGAAGAATGC } & \text { pHIS8 cloning } \\ \text { GASCL2_pHIS8_F } & \text { CGTGGTTCCCATGGCATGGTTCATGAAGAGATGACAACTAAGAC } & \text { pHIS8 cloning } \\ \text { GASCL__pHIS8_R } & \text { TCGAATTCCTCGAGTACACTACTAAGTTCTTGTAAGATGCCTCC } & \text { pHIS8 cloning } \\ \text { GASCL2-B1 } & \text { ATGGTTCATGAAGAGATGACAACTAAGACC } & \text { pJET1.2 cloning } \\ \text { GASCL2-end } & \text { TTACACTACTAAGTTCTTGTAAGAATGCCTTCAAATGTAACC } & \text { pJET1.2 cloning } \\ \text { AP1 } & \text { GTAATACGACTCACTATAGGGC } & \text { GENOM EWALKER } \\ \text { AP2 } & \text { ACTATAGGGCACGCGTGGT } & \text { GENOM EWALKER }\end{array}$


Table S2. Plant species used in construction of the phylogenetic tree and amino acid alignment.

$\begin{array}{ll}\text { Name of the gene/protein } & \text { Species } \\ \text { PpASCL } & \text { Physcomitrella patens } \\ \text { SmPKS2 } & \text { Selaginella moellendorffii } \\ \text { PrCHSL } & \text { Pinus radiata } \\ \text { Os10g0484800 (YY2) } & \text { Oryza sativa } \\ \text { Os07g0411300 } & \text { Oryza sativa } \\ \text { HpPKS1 } & \text { Hypericum perforatum } \\ \text { PtCHSL4 } & \text { Populus trichocarpa } \\ \text { PtCHSL5 XP_002326830 } & \text { Populus trichocarpa } \\ \text { PtCHSL6 XP_002305482 } & \text { Populus trichocarpa } \\ \text { RcCHSL } & \text { Ricinus communis } \\ \text { NsCHSLK } & \text { Nicotiana sylvestris } \\ \text { AtPKSA } & \text { Arabidopsis thaliana } \\ \text { AtPKSB } & \text { Arabidopsis thaliana } \\ \text { AtCHSL } & \text { Arabidopsis thaliana } \\ \text { AhCHSL1 } & \text { Arabidopsis halleri } \\ \text { AhCHSL2 } & \text { Arabidopsis halleri } \\ \text { ZmCHSL } & \text { Zea mays } \\ \text { HvCHSL } & \text { Hordeum vulgare } \\ \text { TaCHSL1 } & \text { Triticum aestivum } \\ \text { TaCHSL } & \text { Triticum aestivum } \\ \text { AtaCHSL } & \text { Aegilops tauschii } \\ \text { Sb01g018950 } & \text { Sorghum bicolor } \\ \text { Sb02g009850 } & \text { Sorghum bicolor } \\ \text { SICHSL } & \text { Silene latifolia } \\ \text { VvCHSL1 } & \text { Vitis vinifera } \\ \text { VvCHSL2 } & \text { Vitis vinifera } \\ \text { GhASCL1 } & \text { Gerbera hybrida } \\ \text { GhASCL2 } & \text { Gerbera hybrida } \\ \text { Gh2PS1 } & \text { Gerbera hybrida } \\ \text { Gh2PS2 } & \text { Gerbera hybrida } \\ \text { Gh2PS3 } & \text { Gerbera hybrida } \\ \text { GhCHS1 } & \text { Gerbera hybrida } \\ \text { GhCHS3 } & \text { Gerbera hybrida } \\ \text { GhCHS4 } & \text { Gerbera hybrida } \\ \text { MsCHS } & \text { edicago sativa } \\ & \end{array}$

$\begin{array}{ll}\text { Amino acid } & \text { Nucleotide } \\ \text { accession no. } & \text { accesion no. } \\ \text { XP_001781520 } & \text { XM_001781468 } \\ \text { XP_002985571 } & \text { XM_002985525 } \\ \text { AAB80804 } & \text { U90341 } \\ \text { NP_001064891 } & \text { NM_001071426 } \\ \text { NP_001059449 } & \text { NM_001065984 } \\ \text { JQ073294 } & \text { JQ073294 } \\ \text { XP_002302511 } & \text { XM_002302475 } \\ \text { XP_002326830 } & \text { XM_002326794 } \\ \text { XP_002305482 } & \text { XM_002305446 } \\ \text { XP_002529257 } & \text { XM_002529211 } \\ \text { CAA74847 } & \text { Y14507 } \\ \text { At1g02050 } & \text { NM_100085 } \\ \text { At4g34850 } & \text { NM_119651 } \\ \text { At4g00040 } & \text { NM_116221 } \\ \text { AAZ81872 } & \text { DQ062307 } \\ \text { AAZ23686 } & \text { DQ062345 } \\ \text { NP_001149508 } & \text { NM_001156036 } \\ \text { AAV49989 } & \text { AH014393 } \\ \text { EU408770 } & \text { EU408770 } \\ \text { CAJ15412 } & \text { CT009735 } \\ \text { CAJ13966 } & \text { CT009625 } \\ \text { XP_002467058 } & \text { XM_002467013 } \\ \text { XP_002461886 } & \text { XM_002461841 } \\ \text { BAE80096 } & \text { AB182106 } \\ \text { CA047307 } & \text { XM_002276617 } \\ \text { CA070579 } & \text { XM_002276606 } \\ & \text { KX550276 } \\ \text { P48391 } & \text { KX550277 } \\ \text { AM Q09636 } & \text { Z38097 } \\ \text { CAA62683 } & \text { KR107540 } \\ \text { P48390 } & \text { KR107541 } \\ \text { P48392 } & \text { Z38096 } \\ \text { CAP20328 } & \text { Z38098 } \\ \text { P30074 } & \text { LO062902 } \\ & \end{array}$


MECHS

GhCHS1

GhCHS3

GhCHS4

Gh2PS1

Gh2PS3

Gh2PS2

Pt CHSL4

Pt CHSL5

HpPKS1

VvCHSL2

NsCHSLK

GhASCL1

At PKSA

AhCHSL1

At CHSL

Os10g0484800_YY2

TaCHSL1

Sb01g018950

PrCHSL

Os 07g0411300

HvCHSL

TaCHSL

At aCHSL

ZmCHSL

Sb02g009850

Pt CHSL6

$\mathrm{RcCHSL}$

VVCHSL1

At PKSB

AhCHSL2

SI CHSL

GhASCL2

SmPKS2

PpASCL

$\mathrm{MBCHS}$

GhCHS1

GhCHS3

GhCHS4

Gh2PS1

Gh2PS3

Gh2PS2

Pt CHSL4

Pt CHSL5

HpPKS1

VvCHSL2

NsCHSLK

GhASCL1

At PKSA

AhCHSL 1

At CHSL

Os 10g0484800_YY2

TaCHSL1

Sb01g018950

PrCHSL

Os07g0411300

HvCHSL

TaCHSL

At aCHSL

ZnCHSL

Sb02g009850

Pt CHSL6

RcCHSL

VVCHSL1

At PKSB

AhCHSL2

SI CHSL

GhASCL2

SmPKS2

PpASCL

\section{MECHS}

GhCHS1

GhCHS3

GhCHS4

Gh2PS1

Gh2PS3

Gh2PS2

Pt CHSL4

Pt CHSL5

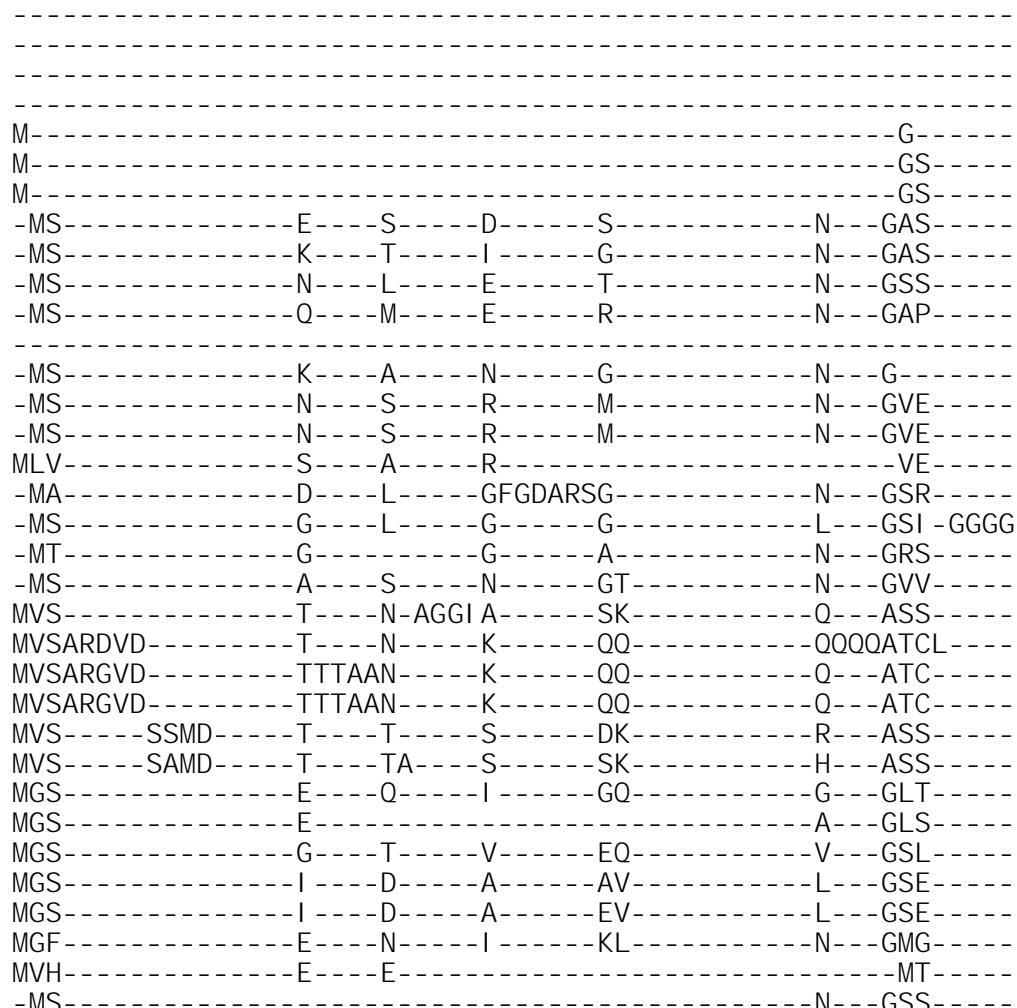

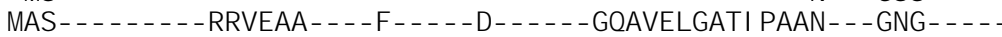

M - - - - - VSVSEI RKA- - ORAEGP- - ATI LAI GTANPANCVEOSTYPDFYFKI

- - - - - MASS- - - VDMKAI RDA- - QRAEGP - ATI LAI GTATPANCVYQADYPDYYFRI - . - . - - - M - - . - VNI EEFRKA- - QRAEGP. - ATI MAI GTATPSNCVFQDTYPDYYFRV - - - S- YSS- - - - - - DDVEVI REA- - GRAQGL- - ATI LAI GTATPPNCVAQADYADYYFRV - - - S- YGT - - - - - VDVEAI REA- - QRAQGL- - ATI LAI GTATPPNCFI QADYPDYYFRV - - - S- YPA - - - - - I DVEAI RES- - QRGQGL- - ATI LAI GTAVPPYCFYQADYPDYYFRV - . - K- HCT - . - . - . - . - . - TPS- - RRAPTLGKATLLAI GKAFPSQLI PQECLVEGYI RD

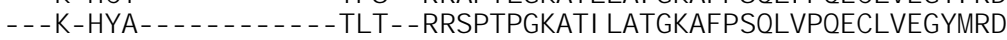
-

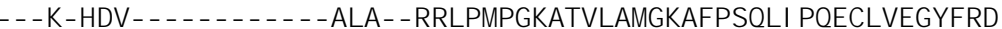
- . - - - N- GNS - - - - - - - - - SAT - RRAPTPGKATVLAI GKAFPGQLVPQDCLVEGFFRD

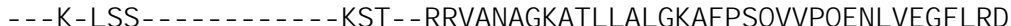

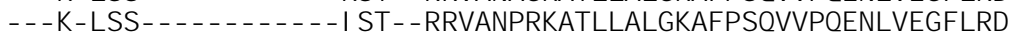

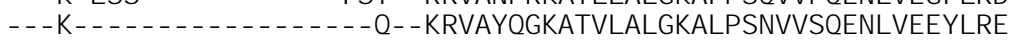

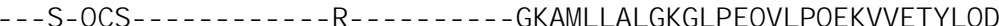

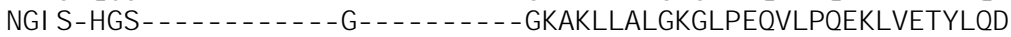

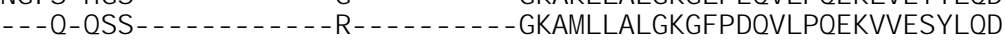

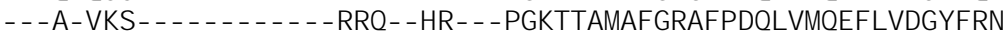
APNPGKATI LALGHAFPQQLVMDOYVDGFMRN - 2 - 2 APNPGKATI LALGHAFPQQLVMQDYWEGFMRN APNPGKATI LALGHAFPQQLVMDDYVEGFMRN APNPGKATI LALGHAFPOQLVMDDYWEGFMRN - . - . KASPGKATI LALGKAFPHQLVMQEFLVDGYFKN

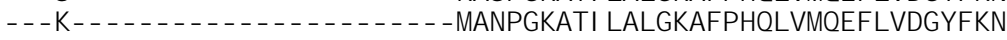
KANPGKATI LALGKAFPHQLVMDEFLVDGYFRN KSNPGKATI LALGKAFPHQLVMDEYLVDGYFKT - KPTPGKATVLSLGKGFPHTLVMQEFLVDGYFRN

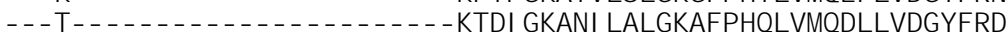
- - - S- GVK - - . - . - . - . - RKN - LRAARPGKATLLAFGKALPDTVKQEYLVDGYFRD - . - T- HQS - . - . - . - . - I I KVPGHRQVTPGKTTI MAI GRAVPANTTFNDGLADHYI QE

TNSEHKTELKEKFQRMCDKSM KRRYMYLTEEI LKENPNVCEYM - - APSLDARQDMWW TKSEHMNDLKEKFKRMCDKSM RKRYMHI TEEYLKQNPNMCAYM - - APSLDVRQDLWW TESEHMNDLKEKFQRMCDKSM RKRYMH TEEFLKENPSMCKFM - - APSLDARQDLW TKSEHKTELKEKFKRMCDKSM KKRYMYLTEEI LEEKPNVCAYM - - APSLNERQDI WV TKSEHMNDLKEKFKRI CEKTAI KKRYLALTEDYLQENPTMCEFM - - APSLNARQDLWT TKSEHMNELKEKFKRI CDKTAI KKRYLALTEEYLKQNPSMCEFM - - APSLNARQDLI VP TKSEHMNDLKEKFKRVCEKTAI KKRYLVLTEDYLEKNPNMGEFM - - APSFNARQDLVVP TKCDDAS- I KEKLERLCKTTTVKTRYTVMSREI LDKYP- - - ELATEGTPTI RQRLEI ANP TKCDDAS- I KEKLERLCKTTTVKTRYTVMSKEI LEKYP- - - ELATEGSPTI KQRLEI ANP 
HpPKSI

VvCHSL2

NsCHSLK

GhASCL1

At PKSA

AhCHSL 1

At CHSL

Os 10g0484800_YY2

TaCHSL1

Sb01g018950

PrCHSL

Os 07g0411300

HvCHSL

TaCHSL

At aCHSL

ZnCHSL

Sb02g009850

Pt CHSL6

RcCHSL

VvCHSL1

At PKSB

AhCHSL2

SI CHSL

GhASCL2

SmPKS2

PpASCL

$\mathrm{M}$ CHS

GhCHS1

GhCHS3

GhCHS4

Gh2PS1

Gh2PS3

Gh2PS2

Pt CHSL4

Pt CHSL5

HpPKS1

VvCHSL2

NsCHSLK

GhASCL1

At PKSA

AhCHSL 1

At CHSL

Os 10g0484800_YY2

TaCHSL1

Sb01g018950

Pr CHSL

Os 07g0411300

HvCHSL

TaCHSL

At aCHSL

ZnCHSL

Sb02g009850

Pt CHSL6

RcCHSL

VvCHSL1

At PKSB

AhCHSL2

$\mathrm{SI}$ CHSL

GhASCL2

SMPKS2

PpASCL

$\mathrm{M}$ CHS

GhCHSI

GhCHS3

GhCHS4

Gh2PS1

Gh2PS3

Gh2PS2

Pt CHSL4

Pt CHSL5

HpPKSI

VvCHSL2

NsCHSLK

GhASCL1

At PKSA

AhCHSL1

At CHSL

Os 10g0484800_YY2

TaCHSL 1
TKCTDAA- I KEKLERLCETTTVKTRYTVMCKEVLDKYP- - - ELAVEGSPTI RQRFEI ANS TKCODLA- I KEKLERL CKTITVKTRYTVMSKEI LEKYP- - - ELATEGSPTI KOKLEI ANP TNCQDLA- I KEKLERLCKTTTVKTRYTVMSKEI LDKYP- - - ELATEGTPTI KQRLEI ANP TNCMDVA- MKEKLERLCKTTTVKTRYTVMSKEI LDKYP- - - ELATEGSPTI TQRLDI ANK TKCDDAF - I KEKLEHLCKTITVKTRYTVLTREI LAKYP - - ELTTEGSPTI KORLEI ANE TKCDDAF - I KEKLEHLCKTITVKTRYTVLSREI LDKYP- - - ELTTEGSPTI KQRLEI ANE I KCDNLS- I KDKLQHLCKSTTVKTRYTVMSRETLHKYP- - - ELATEGSPTI KQRLEI AND TI CDDPA- TRAKLERLCKTITVRTRYTVMSKELLDEHP - - - ELRTEGTPTLTPRLDI CNA TSCDDPA- TRAKLERLCKTTTVRTRYTVMSKELLDEYP. - - ELKTEGSPTLTPRLDI CNA SSCDDPA- TRAKLERLCTTTTVRTRYTVMSKELLDKHP- - - ELKMEGTPTLTPRLDI CNA TNCQDPV- LRQKLERLCKTTTVKTRYWMSDEI LAQHP- - - ELAVEGSATVRQRLEI SNV TNCDDPE- LKEKLTRLCKTITVKTRYWMSEEI LKSYP. - - ELAOEGOPTMKORLDI SNK TNCNDPE- LKEKLTRLCKTITVKTRYWMSEEI LKSYP- - - ELAQEGLPTMKQRLDI SNK TNCNDPE- LKEKLARLCKTITVKTRYWMSDEI LKSYP. - - ELAQEGLPTMKQRLDI SNK TNCNDPE- LKEKLARLCKTITVKTRYWMSDEI LKSYP- - - ELAOEGLPTMKORLDI SNK TNCDDPE- LKEKLTRLCKTTTVRTRYWMSDEI LKNYP- - - ELAQEGLPTMNQRLDI SNA TNCDDPE- LKEKLTRLCKTTTVKTRYWMSEEI LKNYP - - ELAQEGLPTMKQRLDI SNA TNCDDPE- LKOKLTRLCKTITVKTRYWMSDEI LNKYP- - - ELAI EGI PTI KORLDI CND TNCDDPE- LKQKLTRLCKTITVKTRYWMSEEI LEKYP- - - ELAVEGLPTLKQRLDI CNE TNCDDPD- LKEKLARLCKTTTVKTRYWMSEEI LRKYP- - - ELVI EGQPTVKQRLDI CNK TKCDDPE- LKOKLTRLCKTITVKTRYWMSEEI LKKYP- - - ELAI EGGSTVTORLDI CND TKCDDPE- LKQKLTRLCKTITVKTRYWMSEEI LKKYP - - - ELAI EGGSTVTQRLDI CND TNCDDPE- LKQKLTRLCKTITVKTRYWMSDEI LKKCP- - - ELAMAGQATVKQRLDI CND TNCDDPE- LKRKLI RLCKTITVKTRYWMSOEI LKKYP- - - ELALEGLPTVKORLDI CNK TKVENAA- LKEKLORLCKTITVKTRYWMSKEI LENHP- - - EFYTPGTPSI RQRLEI AGE FNLQDPV- LQAKLRRLCETTTVKTRYLWNKEI LDEHP. - - EFLVDGAATVSQRLAI TGE

EVPRLGKEAAVKAI KEUGOPKSKI THLI VCTTSGVDMPGADYQLTKLLGLRPYVKRYMMY EVPKLGKEAAMKAI KEVGHPKSKI THLI FCTTSGVDMPGADYQLTKLLGLRPSVKRFMMY EVPKLGKEAATKAI KEWGFPKSKI THLVFCTTSGVDMPGADYQLTKLLGLRPSVKRLMMY EVPKL GKEAATRAI KEWGOPKSKI THLVFCTTSGVDMPGADYOLTKLLGLRPSVKRLMMY GVPMLGKEAAVKAI DEWGLPKSKI THLI FCTTAGVDMPGADYQL VKLLGLSPSVKRYMLY GVPMLGKEAAVNAI QEVGHPKSKI THLI FCTTAGVDMPGADYQLI KLLGLSPSI SRYMMY EVPKL GKEAAI KAI DEWGHSKSKI THLI FCTTAGVDMPGADYQL TKLLGLSPSVKRYMMY AWVMALKASMACI NEWGGSVEDI THI VYVSSSEVRLPGGDLYLASQLGLRNDVGRVMLY AWVMALKASI ACI NEWGGSVKDI THWYVSSSEI RLPGGDLYLASQLGRNDVGRVMLY AWEMAI EASHACI KEWGRPI SEI THWYVSSSELRLPGGDLYLASELGLRTDVRRVMY AVLQMAMEASLACI EEVGRPVGDI THI VYVSSSEI RLPGGDLYLASQLGLRSDVGRI MYY AWEMAKQASQACI KEWGRSAEEI THI VYVSSSEI RLPGGDLYLATELGLRNDI GRVMY AVTEMAKDASLACI KOMGRPAGDI THWYVSSSEI RLPGGDLYLASELGLRNDVNRVMY AWEMALEASLGCI KEWGRPVEDI THI WYVSSSEI RLPGGDLYLSAKLGLRNDVNRVMY AVVEMLEASLGCI KEWGRPVEDI THI VYVSSSEI RLPGGDLYLSAKLGLRNDVNRVMLY AWOMAYEASLVCI KEWGRAVEDI THLVYVSSSEFRLPGGDLYLSAQLGLSNEVORVMY AVLELGATAARAALGEWGRPAADI THLVYI SSSELRLPGGDLFLATRLGLHPNTVRTSLL AVLELGAAAARAALGEVGRPAADI THLVYI SSSELRLPGGDLFLATRLGLSPNTVRTSLL AVI DLGAAAARAALDDVGRPAADI THLI YI SSSELRLPGGDVHLAARLGLSPNTVRTSLL AVTDMAVDACRDCLKEWGRPVSEI THLVYVSSSEI RLPGGDLYLASRLGLRSDVSRVMY AVTOMATEASLACVRSWGGALSEI THLVYVSSSEARFPGGDLHLARALGLSPDVRRVMA AVTOMATEASLACVEAWGGDLSAI THLVYVSSSEARFPGGDLHLARALGLSPDVRRVMA AVTOMATEASLACVKAWGGDL SAI THLVYVSSSEARFPGGDL HLARALGL SPDVRRVMA AVTQMATEASLACVKAVGGDLSAI THLVYVSSSEARFPGGDLHLARALGLSPDVRRVMA AVTQMATEASLSCVRSWGGALSSI THLVYVSSSEARFPGGDLHLARALGLSPDVRRVMA AVTOMATEASLSCVRSWGGALSSI THLVYVSSSEARFPGGDLHLARALGLSPDVRRVMA AVTOMAI GASRACI KKWGRSVSDI THMYYSSSEARLPGGDLYLAGGLGLSPETQRVMLY AVTKMAI EASQKCI KNMGRPI SDI THLVYVSSSEARLPGGDLHLARGLGLSPETQRVTLY AVTOMAI DASKACI KKUGRSVSEI THLVYVSSSEARLPGGDLYLAKGLGLSPETHRVQLY AVTEMAVEASRACI KNWGRSI SDI THMYVSSSEARLPGGDLYLAKGLGLSPDTHRVLLY AVTEMAVEASRACI KNWGRSI SEI THLVYVSSSEARLPGGDLYLAKGLGLSPDTHRVLLY AVTEMAI DASKACI SDUGRPI SDI THLVYVSSSEARLPGGDLYLAKGLGLSPETNRVMLY AVTOMAI EASOACI KNMARPI SDI THLVYVSSSEARLPGGDLYLAKGLGLSPNTNRVMYY AVTKMGVAAATQALAEWGRPI SDI THLVYVSSSEVRFPGGDLYLSKHLGLSSDI SRVMLY AVTQLGHEAATAAI KEWGRPASEI THLVYVSSSEI RLPGGDLYLAQLLGLRSDVNRVMLY

QQGCFAGGTVLRLAKDLAENN- KGARVLWCSEVTAVTTFRGPSDTHLDSLVGQALFGDGA QQGCFAGGTVLRLAKDLAENN- KGARVLWCSEI TAVTFRGPNDTHLDSLVGQALFGDGA OQGCFAGGTVLRLAKDLAENN- KGARVL WCSEI TAVTFRGPNEGHLDSL VGOALFGDGA QQGCFAGGTVLRLAKDLAENN- KGARVLWCSEI TAVTFRGPDETHLDSLVGQALFGDGA QQGCAAGGTVLRLAKDLAENN- KGSRVLI VCSEI TAI LFHGPNENHLDSLVAQALFGDGA QOGCSAGGMLRLAKDLAENN- KGSRVLWCCEI TAI I FRGPNENHIDSL VGOALFGDGA QQGCAAGGMLRLAKDLAENN- KDSRVLVI CSEI TTI I FRGPDEQHI DSLVGQALFGDGA FLGCYGGVTGLRVAKDI AENN- PGSRVLLTTSETTI LGFRPPSKARPYDLVGAALFGDGA FLGCYGGVTGLRVAKDI AENN- PGSRI LLTTSETTI LGFRPPNKARPYDLVGAALFGDGA FLGCYGGVTGLRVAKDI AENN- PGSRVLLTTSETTI LAFRPPSNARPYDLVGAALFGDGA FLGCYGGVTGLRVAKDI AENN- PGSRVLLTTSETTI LGFRPPNKERPYDLVGAALFGDGA FLGCYGGVTGLRVAKDI AENN- PGSRVLLTTSETII LGFRPPNKARPYDL VGAALFGDGA FLGCYGGVTGLRI AKDI AENN- PGSRVLLTTSETTI LGFRPPNKSRPYDLVGAALFGDGA FLGCYGGVTGLRVAKDI AENN- PGSRVLLTTSETTI LGFRPPNKARPYDLVGAALFGDGA FLGCYGGVTGLRVAKDI AENN- PGSRVLVTTSETTI LGFRPPNKARPYDLVGAALFGDGA FLGCYGGLSGLRVAKDI AENN- PGSRVLLTTSETTVLGFRPPNKARPYNLVGAALFGDGA FLGCSGGAAALRTAKDI AENN- PGSRVLWAAETTVLGFRPPSPDRPYDLVGAALFGDGA FLGCSGGAAALRTAKDI AENN- PGSRVLVI AAETTVLGFRPPSPDRPYDLVGAALFGDGA 
Sb01g018950

PrCHSL

Os07g0411300

HvCHSL

TaCHSL

At aCHSL

ZnCHSL

Sb02g009850

Pt CHSL6

RcCHSL

VVCHSL1

At PKSB

AhCHSL2

SI CHSL

GhASCL2

SmPKS2

PpASCL

MECHS

GhCHS1

GhCHS3

GhCHS4

Gh2PS1

Gh2PS3

Gh2PS2

Pt CHSL4

Pt CHSL5

HpPKS1

VvCHSL2

NsCHSLK

GhASCL1

At PKSA

AhCHSL1

At CHSL

Os10g0484800 YY2

TaCHSL 1

Sb01g018950

Pr CHSL

Os 07g0411300

HvCHSL

TaCHSL

At aCHSL

ZnCHSL

Sb02g009850

Pt CHSL6

RcCHSL

VVCHSL1

At PKSB

AhCHSL2

SI CHSL

GhASCL2

SmPKS2

PpASCL

MECHS

GhCHS1

GhCHS3

GhCHS4

Gh2PS1

Gh2PS3

Gh2PS2

Pt CHSL4

Pt CHSL5

HpPKS1

VvCHSL2

NsCHSLK

GhASCL1

At PKSA

AhCHSL1

At CHSL

Os 10g0484800_YY2

TaCHSL1

Sb01g018950

PrCHSL

Os07g0411300

HvCHSL

TaCHSL

At aCHSL

ZnCHSL

Sb02g009850
FLGCSGGAAALRTAKDI AENN- PGSRVLVTAAETTVLGFRPPSYDRPYDLVGAALFGDGA FLGCYGGVTGLRVAKDLAENN- PGSRVLLATSETTI LGFRPPNPERPYDLVGAALFGDGA FTGCSGGVAGLRVAKGLAESC- PGARVLLATSETTI VGFRPPSPDRPYDLVGVALFGDGA FTGCSGGVAGLRVAKGLAESC- PGARVLLATSETTVAGFRPPSPDRPYDLVGVALFGDGA FTGCSGGVAGLRVAKGLAESC- PGARVLLATSETTVAGFRPPSPDRPYDL VGVALFGDGA FTGCSGGVAGLRVAKGLAESC- PGARVLLATSETTVAGFRPPSPDRPYDLVGVALFGDGA FTGCSGGVAGLRVAKGLAESC- PGARVLLATSETTI VGFRPPSPDRPYDLVGVALFGDGA FTGCSGGVAGLRVAKGLAESCGPGARVLLATSETTI VGFRPPSPDRPYDLVGVALFGDGA FSGCSGGVAGLRVAKDI AENN- PGSRVLLATSETTI I GFKPPSVDRPYDLVGVALFGDGA FMGCSGGVSGLRI AKDI AENN- PGSRVLLATSETTI I GF KPPSADRPYDLVGVALFGDGA FMGCSGGVAGLRVAKDI AENN- PESRVLLATSETTI I GFKPPSADRPYDLVGVALFGDGA FVGCSGGVAGLRVAKDI AENN- PGSRVLLATSETTI I GFKPPSVDRPYDLVGVALFGDGA FVGCSGGVAGLRVAKDI AENN- PGSRVLLATSETTI I GFKPPSVDRPYDLVGVALFGDGA FSGCSGGVAGFRVAKDI AENN- PGSRVLLATSETTI I GFKPPNPDRPYDLVGVALFGDGA FAGCSGGVAGLRVAKDI AENN- PGSRVLLATSETTI I GFKPPSI NRPYDLVGVALFGDGA MLGCCGGAGGLRVSKDLAENN- PGSRI LLVI SDTTLI GWRPPNPQRPYDLVGAALFGDGA MLCYGGASGI RVAKDLAENN- PGSRVLLI TSECTLI GYKSLSPDRPYDLVGAALFGDGA

AALI VGSDPVPEI - EKPI FEMVTAAQTI APDSEGAI DGHLREAGLTFHLLKDVPGI VSKN AAVI VGSDPDLTT- ERPLFEMVSAAOTI LPDSEGAI DGHLREVGLTFHLLKDVPGLI SKN AAVI I GSDPDLSV- ERPLFEMVSAAQTI LPDSEGAI DGHLKEVGLTFHLLKDVPALI AKN AAI I VGSDPLLGQ- EKPLFEMYYAQTI LPDSEGAI DGHLREVGLTFHLLKDVPGLI SKH AALI VGSGPHLAV- ERPI FEI VSTDOTI LPDTEKAMKLHLREGGLTFOLHRDVPLMNAKN AALI VGSDPDLAT- ERPLFEI VSTDOTI LPDSEKAMKLHLREEGLTFOLHRDVPTM GKN AAI I VGSDPDMTT- EHPLFEI VSTYQTI LPDTEKAMKLHLREEGLTFQLHRDVPLMNSKN AAVI I GANPVI GK- ESPF MELNYSVQQFLPGTONVI DGRLSEEGI HFKLGRDLPQKI EDN AAVI I GADPVI GK- ESPF MELSYAVOOFLPGTONVI DGRLSEEGI NFKLGRDLPOKI EDN AAVI I GTNPVAGK- ESPF MELNYATQQFLPGTQSI VDGKLHEEGI NFKLGRDLPQKI EDN AAVI VGTDPI PGK- ECPFMELNHAVOOFLPGTHNVI DGRLSEEGI NFKLGRDLPAKI EEN AAVI I GTEPI MGK- ESPF MELNFATQOFLPGTNMVI DGRLTEEGI NFKLGRDLPEKI QDN AAAI I GAEPI TKV- ESPFLELNYAVQQFLPGTHNVI DGRLSEEGI NFKLGRDLPQKI DDN AAVI I GADP- REC- EAPF MELHYAVQQFLPGTONVI EGRLTEEGI NFKLGRDLPQKI EEN AAVI I GADP- REC- EAPF MELHYAVOOFLPGTOMVI DGRLTEEGI NFKLGRDLPOKI EEN AALI I GADP- TES- ESPF MELHCAMQQFLPQTQGVI DGRLSEEGI TFKLGRDLPQKI EDN SAAI I GAGPI AAE- ESPFLELQFSTQEFLPGTDKVI DGKI TEEGI NFKLGRDLPEKI ENR SAAI I GASPI KAE- EDPFLELEFSTOEFLPGTDKVI DGKI SEEGI NFKLGRDLPEKI ESR SAVI I GAGPMAPA- EDPFLELEFSTQEFLPGTDKVI DGKI AEEGI NFKLGRDLPEKI ESR AAMNLGTDPRPEAGEQGF LELDWAVQOFLPDTHGTI NGRLTEEGI NFKLGRELPQ I EDH GAAVGADPTPV- - ERPLFELHSALORFLPDTDKTI DGRLTEEGI KFQLGRELPHI I EAN GAAVGADPTAV- - ERPLFELHSALORFLPDTEKTI DGRLTEEGI KFOLGRELPH I EAH GAAWGTDPTPL- - ECPLFELHSALQRFLPGTEKTI DGRLTEEGI KFQLGRELPHI I EAH GAAVGTDPTPL- - ERPLFELHSALQRFLPDTEKTI DGRLTEEGI KFQLGRELPHI I EAH GAAVI GTDPAPA - ERPLFELHSALORFLPDTERTI EGRLTEEGI KFQLGRELPHI I EAH GAAVI GTDPAPG - ERPLFELHSALQRFLPDTEKTI EGRLTEEGI KFQLGRELPHI I EAH GAMVI GTDPVPVT- ESPLFELHTAI QNFLPNTEKTI DGRLTEEGI SFKLARELPQI I EDN GAM I GTDPVSKT- ESPLFELHTAI ONFLPDTEKI I DGRLTEEGI SFKLARELPHI I EDN GAM I GSDPI PST- ERPLFELHTAI QNFLPDTEKTI DGRLTEEGI SFKLARELPQ I EDH GAM I GSDPDPI C- EKPLFELHTAI QNFLPETEKTI DGRLTEQGI NFKLSRELPQ I EDN GAM I GSDPDPVC- EKPLFELHTAI ONFLPDTEKTI DGRLTEOGI NFKLARELPO I EDN GAM I GSDPNSS- - ENPLFELHTAI QHFLPDTEKI I DGRLTEEGI SFTLDRALPQ I EDN GAM I GSGPVSGL- ESPLFELHTAI QNFLPDTEKVI DGRLTEEGI SFKLSRELPEI I EEN SAWI GADPLP- S- ENPCYELVTASOCFVPGSEKTI DGRLTEDGI I FSLGRELPOM ESE AAM MGKDPI PVL- ERAFFELDMAGQSFI PGTNKTI DGRLSEEGI SFKLGRELPKLI ESN

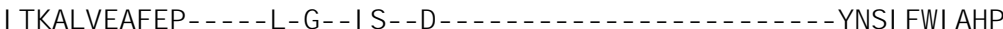

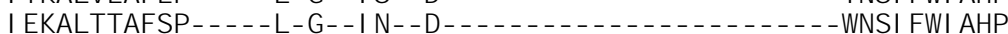
I EKALI QAFSP - . - L- N- I N- D - .

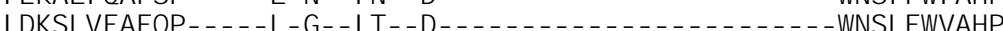

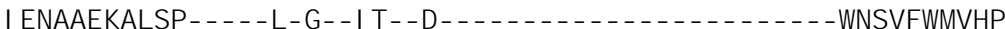

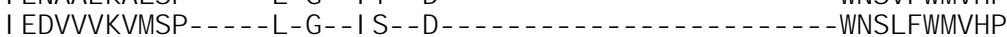

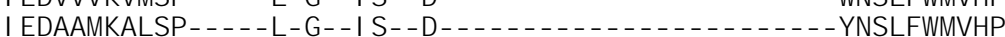

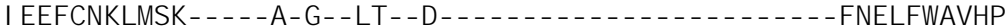

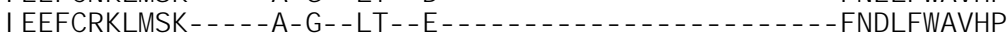
I EEFCKKI MSE- - - A- G - LT- Q - -

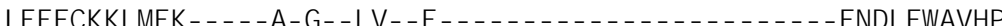

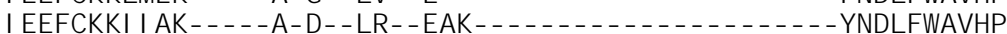
I EGFCKKLI EK- - A - G - LG - D - Q - - FNDLFWAVHP

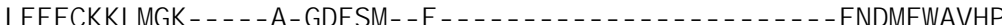

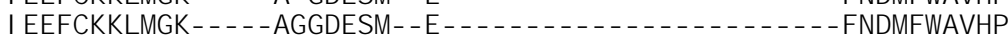
VEEFCKKLVAK- - - - A- GSGAL - E- - - _ -

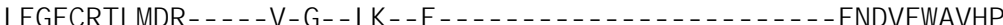

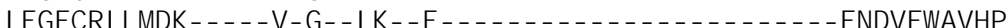
I EGFCRTLMNQ - . - V- G - I K- - D - . . . . - . - FNDVFWAVHP

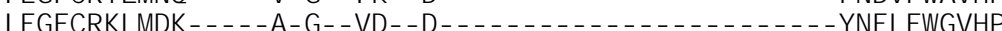

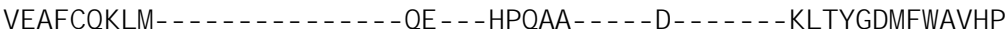

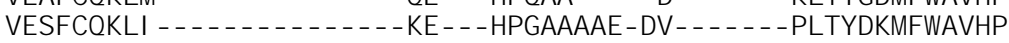

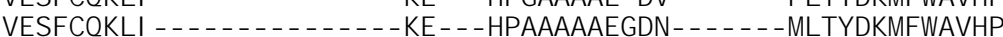

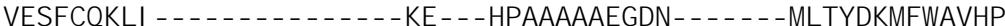

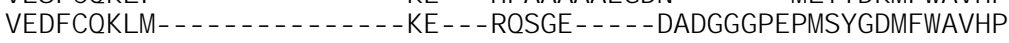

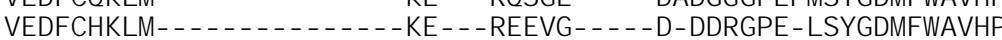


Pt CHSL6 RcCHSL

VvCHSL1 At PKSB

AhCHSL2

SI CHSL

GhASCL2

SmPKS2

PpASCL

$\mathrm{MECHS}$

GhCHS1

GhCHS3

GhCHS4

Gh2PS1

Gh2PS3

Gh2PS2

Pt CHSL4

Pt CHSL5

HpPKS1

VvCHSL2

NSCHSLK

GhASCL1

At PKSA

AhCHSL1

At CHSL

Os 10g0484800_YY2

TaCHSL1

Sb01g018950

PrCHSL

Os07g0411300

HvCHSL

TaCHSL

At aCHSL

ZnCHSL

Sb02g009850

Pt CHSL6

RcCHSL

VVCHSL1

At PKSB

AhCHSL2

SI CHSL

GhASCL2

SmPKS2

PpASCL

MECHS

GhCHS1

GhCHS3

GhCHS4

Gh2PS1

Gh2PS3

Gh2PS2

Pt CHSL4

Pt CHSL5

HpPKS1

VvCHSL2

NSCHSLK

GhASCL1

At PKSA

AhCHSL1

At CHSL

Os 10g0484800_YY2

TaCHSL1

Sb01g018950

PrCHSL

Os 07g0411300

HvCHSL

TaCHSL

At aCHSL

ZnCHSL

$\mathrm{Sb02g009850}$

Pt CHSL6

RcCHSL

VVCHSL1

At PKSB

AhCHSL2

SI CHSL

GhASCL2

SmPKS2

PpASCL

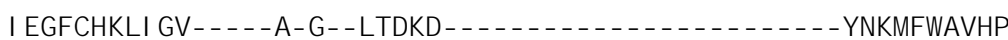

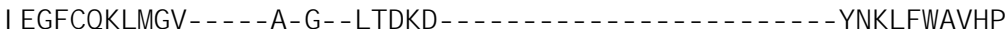
I EAFCDKLI RN - - - V- G - FSDED - - . - . - . - . - YNKI FWAVHP

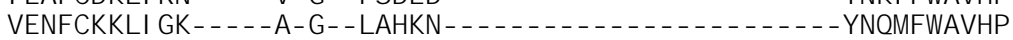
VENFCKKLI GK- . I EAFCDKLMSS- - - - V- G - LTSKD - . - .

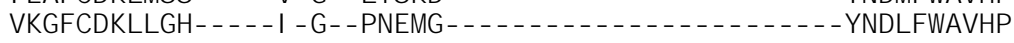

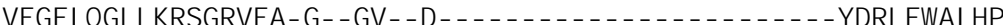

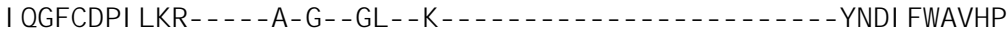

GGPAI LDOVEOKLALKPEKMNATREVLSEYGNMSSACVLFI LDEMRKKST- Q - - NGL- GGPAI LDQVELKLGLKEEKLRATRHVLSEYGNMSSACVLFI I DEMRKKSS- E- - - NGA- GGPAI LDQVEFKLGLREEKLRASRHVLSEYGNMSSACVLFI LDEMRKKSI - K- - - DGK- GGPAI LDQVEEKLGLEPDKLRATRHVLSEYGNMSSACVLFI LNEMRHSSA- T- - - DGL- GGRAI LDQVERKLNLKEDKLRASRHVLSEYGNLI SACVLFI I DEVRKRSM A - - EGK- GGRAI LDQVELKLDLKKEKLRASRHVLSEYGNLTSACVLFI I DEMRKKSV- E- - - EGK- GGRAI LDEVELKLNLKKEKLRASRHVLSEYGNLTSACVLFI I DEMRKKSM - E- - - DGK- GGPAI LNRLESKLKLNEEKLECSRRALMDYGNVSSNTI VYVLEYMRDE- L- K- - - - RG GGPAI LNRLESNLKLNTEKLECSRRALI NYGNVSSNTI VYVLEYMKEE- L- K- - - - RE- GGPEI LNRVESRLGLNADKLECSRRALMDFGNVSNTVLYVMEYLREE- L- K- - - - RK- GGPAI LNRLESTLKLRSEKLECSRRALMDYGNVSSNTI FYVMEYMREA- L- K - . - RK- GGPAI LNRLENTLKLQSEKLDCSRRALMDYGNVSSNTI FYVMEYMREE- L- K- - - - NK- GGPAI LNRLETTLKLRGDKLDCSRRALMDFGNVSSNTI FYVMEYMRDE- L- M - - - SK- GGPAI LNRLETKLKLEKEKLESSRRALVDYGNVSSNTI LYVMEYMRDE- L- K - . - KK GGPAI LNRLETKLKLEKEKLESSRRALVDYGNSSNTI LYVMEYMREE- L- K- - - - KK- GGPAI LSGLETKLKLKPEKLECSRRALMDYGNVSSNTI FYI MDKVRDE- L- E- - - - KK- GGPAI LNRLEVCLELQPEKLKI SRKALMYGMVSSNTVFYVLEYLRDE- L- K- - - - - K- GGPAI LNRLEVCLELEPDKLKI SRKALMNYGNVSSNTVFYVLEYLRDE- L- K- - - - - K- GGPAI LNRLEFCLELQPEKLKI SRKALKNYGNVSSNTI FYVLEYLRDE- L- K- - - - - K- GGPAI LNRLEKKLSLGPEKLYYSRQALADYGNASSNTI VYVLDAMR- Q- L- K- - . . - . - . GGPAI LTKMEGRLGLDGGKLRASRSALRDFGNASSNTI VYVLENMNEETR- Q - . - RR- GGPAI LTKMEGRLGLDGGKLRASRSALRDFGNASSNTI VYVLENMNEESRRQ- - - - RM GGPAI LTKMEGRLGLDGGKLRASRSALRDFGNASSNTI WYVLENMNEESR- Q - - - R- - GGPAI LTKMEGRLGLDGGKLRASRSALRDFGNASSNTI VYVLENMNEESR- Q - - - R- . GGPAI LTKMEGRLGLGADKLRASRCALRDFGNASSNTI VYVLENMNEDTR- R- - - - RR- L GGPAI LTKMEGRLGLGADKLRASRCALRDFGNASSNTI VYVLENMNEETR- R- - - - RK- L GGPAI LNRMEKRLDLLPDKL NASRRAL MDYGNASSNTI WVLEYM EESR- K - . . MK GGPAI LNRMEKRLDLFPEKLNASRRALMDYGNASSNTI VYVLEYM EESL- K- - - - MK- GGPAI LNRMEKRLDLLPEKLNASRRALADYGNASSNTI VYVLEYMLEESS- K- - - - TKRGGPAI LNRI EKRLNLSPEKLSPSRRALMDYGNASSNSI VYVEYMEESK- KVRN- MN- GGPAI LNRMEKRLNLSPEKLSPSRRALMDYGNASSNSI VYVLEYMEESK- KVRN- MN- GGPAI LNRLEKRLDLSPDKLSASRRALTDYGNASSNTI VYVMEYM EEGL- K- - - - RK- GGPAI LNRLEKKFDLWPEKLSASRRALADYGNASSNTI VYVLEYLI EESL- K- - - - MK- GGPAI LNACEKKLQLAGDKLKCSROVLSDYGNI NGSTI I YVLDYMROV - . . . . . . . . GGPAI LNAVQKQLDLAPEKLQTARQVLRDYGNI SSSTCI YVLDYMRHQSL- K- - - - LK- -

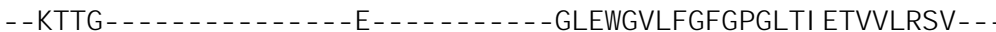
- GTTG - . - . - -

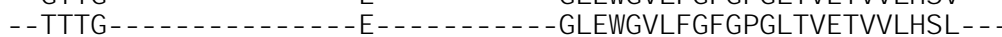
-

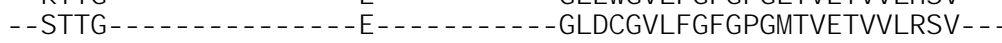

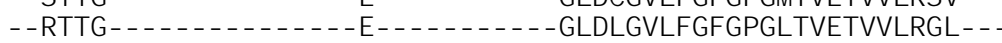

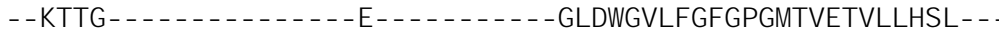
. . . - GG - . . . . . . . . . . . . . . . . . . . . . . .

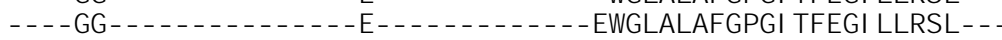

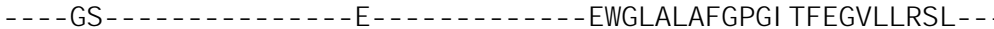

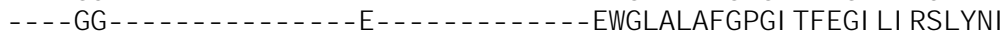

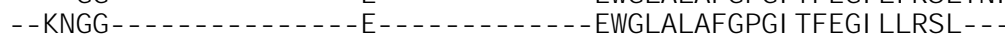

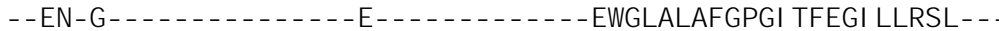
-

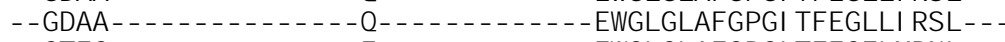
-

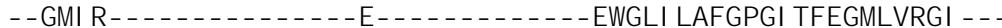

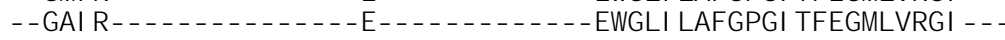
-

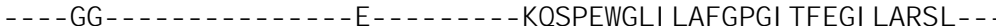

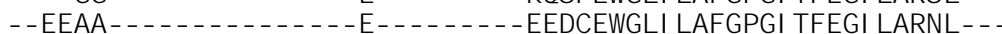
- - TEAPVLENMNEESRRQRTTEPEMEP - . - - - ECEWGLI LAFGPGI TFEGI LARNL- - -

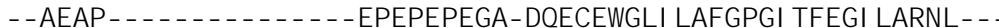
-

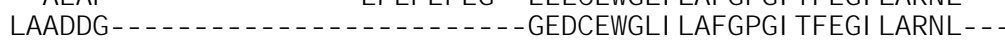

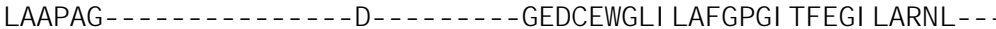
-

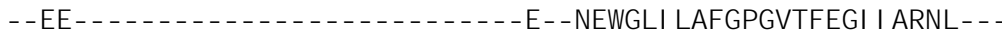
- EE-

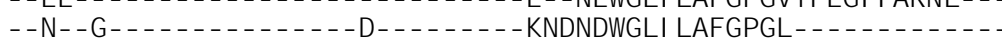

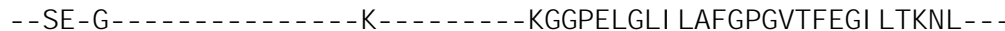

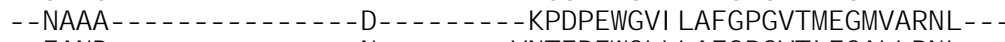

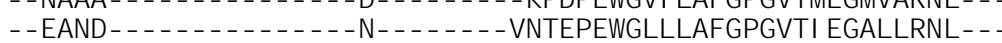




MsCHS
GhCHS1
GhCHS3
GhCHS4
Gh2PS1
Gh2PS3
Gh2PS2
Pt CHSL4
Pt CHSL5
HpPKS1
VvCHSL2
NsCHSLK
GhASCL1
At PKSA
AhCHSL1
At CHSL
Os10g0484800_YY2
TaCHSL1
Sb01g018950
PrCHSL
Os07g0411300
HvCHSL
TaCHSL
At aCHSL
ZnCHSL
Sb02g009850
Pt CHSL6
RcCHSL
VvCHSL1
At PKSB
AhCHSL2
SI CHSL
GhASCL2
SnPKS2
PpASCL

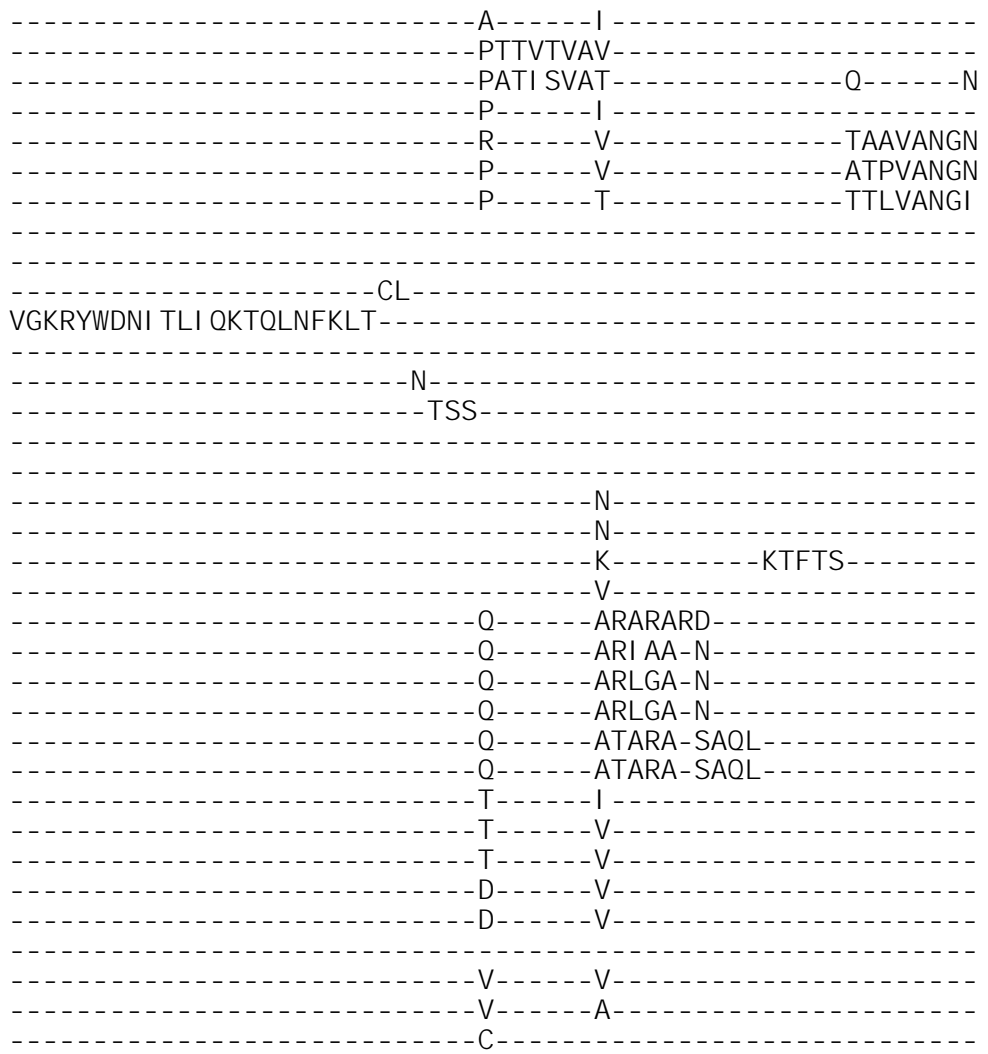

Figure S1. Amino acid alignments of 26 identified or putative ASCLs, gerbera type III PKS family and a CHS from M edicago Sativa generated with prank (www.ebi.ac.uk/goldman-srv/webprank). Grouping to Ala- or Val clades of ASCL proteins is based on the position marked with an asterix. For generating the phylogenetic tree in Figure 1, the alignment was converted to nucleotides. 

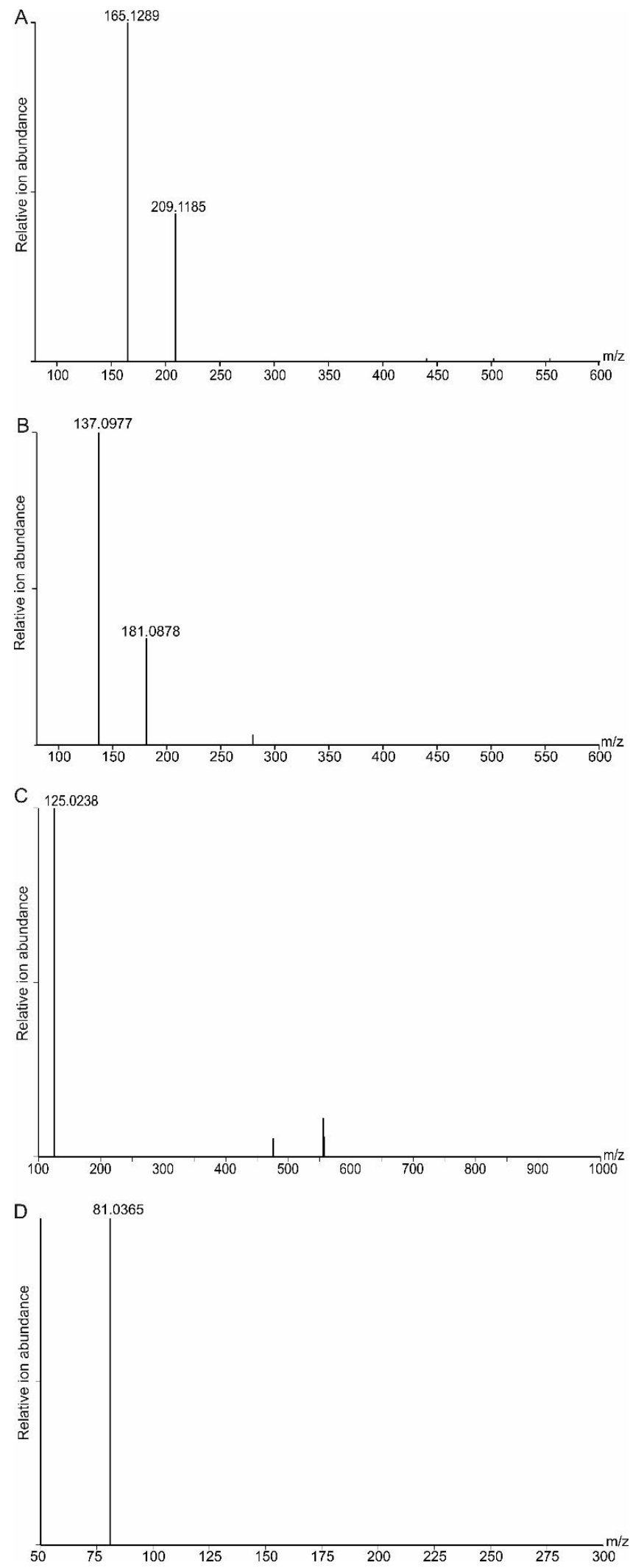

Figure S2. Mass spectra of triketide products produced by GASCL1 and GASCL2. Loss of $\mathrm{CO}_{2}$ was observed in the mass spectra when either hexanoyl-CoA (A), octanoyl-CoA (B) or acetyl-CoA ( $C$ and $D)$ was used in the enzyme assays and remained ions [M - $\left.\mathrm{CO}_{2}-\mathrm{H}\right]$ - with $\mathrm{m} / \mathrm{z} 165$ (A), 137 (B) and 81 (D - M SM S data) were observed. 